Review

\title{
British Airways is Ordering up to 42 Boeing 777-9s Aeronaves to Modernize the UK Flag Carriers Long-Haul Fleet
}

\author{
Relly Victoria Virgil Petrescu \\ ARoTMM-IFToMM, Bucharest Polytechnic University, Bucharest (CE), Romania
}

Article history

Received: 01-03-2019

Revised: 02-03-2019

Accepted: 17-02-2020

Email: rvvpetrescu@gmail.com
Abstract: The Boeing 777 (sometimes referred to as Triple 7) is a largecapacity subsonic long-haul bomber aircraft built by the American company Boeing. This type of aircraft holds the current record of autonomy for commercial jets $(17,450 \mathrm{~km}$ without food). Other special features of the aircraft include the perfect circular fuselage, a set of six wheels on each axle of the landing gear and the ability to be equipped with the high-performance General Electric GE90 engine. The 777 has been exclusively designed using CAD technology (with CATIA version 3), being the first airplane designed without building test structures before. Verification of joints and construction techniques has also been done digitally, with all the structures built up being included in the actual aircraft. The aircraft was designed to serve as an immediately superior Boeing 767 model and was built in airline consultancy (United Airlines, American Airlines, Delta Air Lines, ANA, British Airways, JAL, Qantas and Cathay Pacific) came from United Airlines in 1990 and the first flight took place on June 14, 1994, at the Boeing factory in Everett, near Seattle. It was the first ETOPS 180 bimonthly aircraft (it can fly up to 180 min from any airport able to take it). It is one of the best-selling (two-color) passenger airplanes in history, of which 988 were ordered, of which 635 were already delivered to the airlines. Its main competitors are Airbus A330 (for medium distance routes), Airbus A340 (for long-distance routes, with the claim that this model has the disadvantage of having four engines) and the future of the Airbus A350XWB-1000. Boeing plans to replace the model with the Yellowstone 3 code model in 2012-2015. The aircraft is equipped with modern technologies: Digital flight instruments offered by Honeywell LCD panels, fly-by-wire control, manual back-up systems, fully controllable avionics from software, use of composite materials on a larger surface $(9 \%$ by mass), optical fiber as the primary transmission and control system for avionics, the largest and most powerful engine ever installed in a commercial aircraft (GE90-115B1) and the largest landing gear plus, the landing train allows the highest maximum weight on a wheel of all commercial jets -23.73 t). The aircraft also uses classic technologies - such as the classic jump, unlike the Airbus models that have switched to joysticks. Similarly, the front section (section 41) is identical to that of the Boeing 767. For the comfort of pilots and crew members over long distances, there is a special resting space above the passenger cabin, complete with beds. In fact, the entire interior of the plane was new and then used in other models.

Keywords: Boeing, Boeing 777, Boeing 777-9s, British Airways

\section{Introduction}

Boeing is a US civil and military aircraft manufacturer based in Chicago, USA. Boeing is
Pentagon's second largest provider of aerospace and technological equipment after Lockheed Martin. The company is present in 70 countries around the world.

The company is organized into two main divisions: 
- $\quad$ Boeing Commercial Airplanes

- Boeing Integrated Defense Systems

In June 2008, there were 12,000 commercial airplanes made by Boeing, accounting for about $75 \%$ of the entire commercial fleet in the world.

Civil Aircraft:

- $\quad$ Boeing 247

- Boeing 367-80

- $\quad$ Boeing 707

- Boeing 717

- $\quad$ Boeing 727

- Boeing 737

- Boeing 747

- $\quad$ Boeing 757

- $\quad$ Boeing 767

- $\quad$ Boeing 777

- $\quad$ Boeing 787

Combat planes:

- McDonnell Douglas F/A-18 Hornet

- Boeing F/A-18E/F Super Hornet

- Boeing EA-18G Growler

- F-15 Eagle

- F-15 Strike Eagle

Bombers:

- B-1 Lancer

- B-2 Spirit

- B-17 Flying Fortress

- B-29 Superfortress

- B-47 Stratojet

- B-52 Stratofortress

Tank airplanes:

- KC-135 Stratotanker

- KC-97 Stratotanker

- Strategic transport planes

- $\quad$-17 Globemaster III

Special Aircraft:

- Boeing E-3 SENTRY AWACS

- Boeing E-4B NAOC

- Boeing E-6 MERCURY

- Boeing E-8C JSTARS

Attack helicopters:

- Boeing AH-64 Apache
- Boeing RAH-66 Comanche

Transport helicopters:

- $\mathrm{CH}-47$ Chinook

- H-21 Shawnee

- $\mathrm{CH}-46$ Sea Knight

Experimental Aircraft:

- $\quad$ Boeing X-36

- Boeing X-32 JSF

- Boeing X-45

- Boeing XB-15

- $\quad$ Boeing X-43

- $\quad$ Boeing X-48

Supersonic passenger airplanes:

- $\quad$ Boeing 2707

In March 1910, William E. Boeing bought Heath Shipyard in Seattle on the Duwamish River, which later became his first aircraft factory. Boeing was incorporated into Seattle by William Boeing on July 15, 1916, as "Pacific Aero Products Co.". Boeing was later embedded in Delaware; the original certificate of the establishment was deposited with Delaware State Secretary on July 19, 1934. Boeing, who studied at Yale University, originally worked in the wood industry, where he became rich and learned about wooden structures. This knowledge proved to be invaluable in the design and subsequent assembly of planes. The company stayed in Seattle to take advantage of the local offer of spruce wood.

One of the two B\&W floods built by George Conrad Westervelt, an American engineer, flew on June 15, 1916. Boeing and Westervelt decided to build the B \&W hydrogen after they flew with Curtiss. Boeing bought a Glenn Martin "Flying Birdcage" (named by everyone who held it together) and was taught to fly by Glenn Martin himself. Boeing crashed into Birdcage soon and when Martin informed Boeing that spare parts would not be available for months, Boeing realized he could build the plane at that time. He and Cdr's friend. G.C. Westervelt agreed to build a better aircraft and soon produced the $\mathrm{B} \& \mathrm{~W}$ seaplane. The first Boeing was gathered in a hangar near the lake, located on the northeast shore of Lake Seattle. Many of Boeing's early planes were seaplanes.

On April 6, 1917, the US declared war on Germany and entered the First World War. On May 9, 1917, the company became the company "Boeing Airplane Company". During the war, Boeing knew that the American ship needed training aids. So, Boeing sent two 
new Cs models to Pensacola, Florida, where the planes were fired for the Navy. Marina liked Model C and ordered another 50 people. The company moved its operations to an old building, known as Boeing Plant 1, located on the Lower Duwamish River, Washington.

At the end of the First World War of 1918, a large surplus of cheap and used military aircraft flooded the commercial airplane market, preventing airlines from selling any new aircraft, which led many of them. Others, including Boeing, began selling other products. Boeing built locker rooms, counters and furniture along with flat-bottomed boats called Sea Sleds.

In 1919, Boeing B-1 made the first flight (Hosted a pilot and two passengers and several emails). Within eight years, he made international flights by plane from Seattle to Victoria, British Columbia. On May 24, 1920, Boeing 8 made his first flight. It was the first plane flying over Mount Rainier.

In 1923, Boeing competed against Curtiss to develop a fighter for the US Army Air Service. Although Curtiss completed his project and received the contract, Boeing continued to develop his PW-9 fighter. The plane, along with the Boeing P-12/F4B fighter, made Boeing an important aircraft manufacturer over the next decade.

In 1925, Boeing built his 40 e-mail model for the US government. to use on flight routes. In 1927, an improved version of this $40 \mathrm{~A}$ aircraft was built that won the US mail order to deliver mail between San Francisco and Chicago. The 40A also had a passenger cabin that housed two.

In the same year, Boeing created an airline called Boeing Air Transport, which merged a year later with Pacific Air Transport and Boeing Airline. The first flight to the airline was on July 1, 1927. In 1929, the company merged with Pratt and Whitney, the production company Hamilton Aero Manufacturing and Chance Vought, under the new United Aircraft and Transport Corporation. The merger was followed by the acquisition of Sikorsky Manufacturing Corporation, Stearman Aircraft Corporation and Standard Metal Propeller Company. United Aircraft then acquired the national air transport in 1930.

On July 27, 1928, the 12-passenger Boeing 80 biplane made its first flight. With three engines, Boeing's first aircraft was built with the sole intention of being a passenger transport. A modernized version, 80A, carrying eighteen passengers, made the first flight in September 1929 (Rulkov et al., 2016; Agarwala, 2016; Babayemi, 2016; Gusti and Semin, 2016; Mohamed et al., 2016; Wessels and Raad, 2016; Rajput et al., 2016; Rea and Ottaviano, 2016; Zurfi and Zhang, 2016a; 2016b; Zheng and Li, 2016; Buonomano et al., 2016a; 2016b; Faizal et al., 2016; Ascione et al., 2016; Elmeddahi et al., 2016; Calise et al., 2016; Morse et al., 2016; Abouobaida, 2016; Rohit and Dixit, 2016; Kazakov et al., 2016; Alwetaishi, 2016; Riccio et al., 2016a; 2016b; Iqbal, 2016; Hasan and El-Naas, 2016; Al-Hasan and Al-
Ghamdi, 2016; Jiang et al., 2016; Sepúlveda, 2016; Martins et al., 2016; Pisello et al., 2016; Jarahi, 2016; Mondal et al., 2016; Mansour, 2016; Al Qadi et al., 2016b; Campo et al., 2016; Samantaray et al., 2016; Malomar et al., 2016; Rich and Badar, 2016; Hirun, 2016; Bucinell, 2016; Nabilou, 2016b; Barone et al., 2016; Chisari and Bedon, 2016; Bedon and Louter, 2016; dos Santos and Bedon, 2016; Minghini et al., 2016; Bedon, 2016; Jafari et al., 2016; Chiozzi et al., 2016; Orlando and Benvenuti, 2016; Wang and Yagi, 2016; Obaiys et al., 2016; Ahmed et al., 2016; Jauhari et al., 2016; Syahrullah and Sinaga, 2016; Shanmugam, 2016; Jaber and Bicker, 2016; Wang et al., 2016; Moubarek and Gharsallah, 2016; Amani, 2016; Shruti, 2016; Pérezde León et al., 2016; Mohseni and Tsavdaridis, 2016; Abu-Lebdeh et al., 2016; Serebrennikov et al., 2016; Budak et al., 2016; Augustine et al., 2016; Jarahi and Seifilaleh, 2016; Nabilou, 2016a; You et al., 2016; AL Qadi et al., 2016a; Rama et al., 2016; Sallami et al., 2016; Huang et al., 2016; Ali et al., 2016; Kamble and Kumar, 2016; Saikia and Karak, 2016; Zeferino et al., 2016; Pravettoni et al., 2016; Bedon and Amadio, 2016; Chen and $\mathrm{Xu}, 2016$; Mavukkandy et al., 2016; Yeargin et al., 2016; Madani and Dababneh, 2016; Alhasanat et al., 2016; Elliott et al., 2016; Suarez et al., 2016; Kuli et al., 2016; Waters et al., 2016; Montgomery et al., 2016; Lamarre et al., 2016; Petrescu, 2012b; Aversa et al., 2017a' 2017b; 2017c; 2017d; 2017e; 2016a; 2016b; 2016c; 2016d; 2016e; 2016f; 2016g; 2016h; 2016i; 2016j; 2016k; 2016l; 2016m; 2016n; 2016o; Petrescu and Petrescu, 2013a; 2013b; 2013c; 2012; 2011; Petrescu, 2018; 2015a; 2015b; 2012; Petrescu et al., 2016a; 2016b; 2016c; 2017a; 2017b; 2017c; 2017d; 2017e; 2017f; 2017g; 2017h; 2017i; 2017j; 2017k; 2017l; 2018a; 2018b; 2018c; 2018d; Petrescu and Calautit, 2016a; 2016b; Daud et al., 2008; Taher et al., 2008; Zulkifli et al., 2008; Pourmahmoud, 2008; Pannirselvam et al., 2008; Ng et al., 2008; El-Tous, 2008; Akhesmeh et al., 2008; Nachiengtai et al., 2008; Moezi et al., 2008; Boucetta, 2008; Darabi et al., 2008; Semin and Bakar, 2008; AlAbbas, 2009; Abdullah et al., 2009; Abu-Ein, 2009; Opafunso et al., 2009; Semin et al., 2009a; 2009b 2009c; Zulkifli et al., 2009; Ab-Rahman et al., 2009; Abdullah and Halim, 2009; Zotos and Costopoulos, 2009; Feraga et al., 2009; Bakar et al., 2009; Cardu et al., 2009; Bolonkin, 2009a; 2009b; Nandhakumar et al., 2009; Odeh et al., 2009; Lubis et al., 2009; Fathallah and Bakar, 2009; Marghany and Hashim, 2009; Kwon et al., 2010; Aly and Abuelnasr, 2010; Farahani et al., 2010; Ahmed et al., 2010; Kunanoppadon, 2010; Helmy and El-Taweel, 2010; Qutbodin, 2010; Pattanasethanon, 2010; Fen et al., 2011; Thongwan et al., 2011; Theansuwan and Triratanasirichai, 2011; Al Smadi, 2011; Tourab et al., 2011; Raptis et al., 2011; Momani et al., 2011; Ismail et al., 2011; Anizan et al., 2011; Tsolakis and Raptis, 2011; 
Abdullah et al., 2011; Kechiche et al., 2011; Ho et al., 2011; Rajbhandari et al., 2011; Aleksic and Lovric, 2011; Kaewnai and Wongwises, 2011; Idarwazeh, 2011; Ebrahim et al., 2012; Abdelkrim et al., 2012; Mohan et al., 2012; Abam et al., 2012; Hassan et al., 2012; Jalil and Sampe, 2013; Jaoude and El-Tawil, 2013; Ali and Shumaker, 2013; Zhao, 2013; El-Labban et al., 2013; Djalel et al., 2013; Nahas and Kozaitis, 2014).

\section{Materials and Methods}

British Airways is ordering up to 42 Boeing 777-9s to modernize the UK flag-carrier's long-haul fleet.

Eighteen aircraft are firm orders, complemented by another 24 as options. The twinjets will be fitted with 325 seats in a four-class configuration.

BA parent IAG has disclosed the decision 28 (February, 2019 SOURCE: Flight Dashboard by: David Kaminski-Morrow London).

It says the 777-9s will be used to replace 14 Boeing $747-400$ s as well as four 777-200s over the course of 2022-25.

All the 777-9s will be powered by General Electric GE9X engines and the agreement includes a "comprehensive" support package, says IAG.

IAG chief executive Willie Walsh says the 777-9 is the "ideal replacement" for the 747 (Fig. 1).

The Boeing 777 (sometimes referred to as Triple 7) is a large-capacity subsonic long-haul bomber aircraft built by the American company Boeing. This type of aircraft holds the current record of autonomy for commercial jets $(17,450 \mathrm{~km}$ without food). Other special features of the aircraft include the perfect circular fuselage, a set of six wheels on each axle of the landing gear and the ability to be equipped with the high-performance General Electric GE90 engine.
The 777 has been exclusively designed using CAD technology (with CATIA version 3), being the first airplane designed without building test structures before. Verification of joints and construction techniques has also been done digitally, with all the structures built up being included in the actual aircraft. The aircraft was designed to serve as an immediately superior Boeing 767 model and was built in airline consultancy (United Airlines, American Airlines, Delta Air Lines, ANA, British Airways, JAL, Qantas and Cathay Pacific) came from United Airlines in 1990 and the first flight took place on June 14, 1994, at the Boeing factory in Everett, near Seattle. It was the first ETOPS 180 bimonthly aircraft (it can fly up to $180 \mathrm{~min}$ from any airport able to take it).

It is one of the best-selling (two-color) passenger airplanes in history, of which 988 were ordered, of which 635 were already delivered to the airlines. Its main competitors are Airbus A330 (for medium distance routes), Airbus A340 (for long-distance routes, with the claim that this model has the disadvantage of having four engines) and the future of the Airbus A350XWB-1000. Boeing plans to replace the model with the Yellowstone 3 code model in 2012-2015.

The aircraft is equipped with modern technologies: Digital flight instruments offered by Honeywell LCD panels, fly-by-wire control, manual back-up systems, fully controllable avionics from software, use of composite materials on a larger surface ( $9 \%$ by mass), optical fiber as the primary transmission and control system for avionics, the largest and most powerful engine ever installed in a commercial aircraft (GE90115B1) and the largest landing gear plus, the landing train allows the highest maximum weight on a wheel of all commercial jets $-23.73 \mathrm{t}$ ).

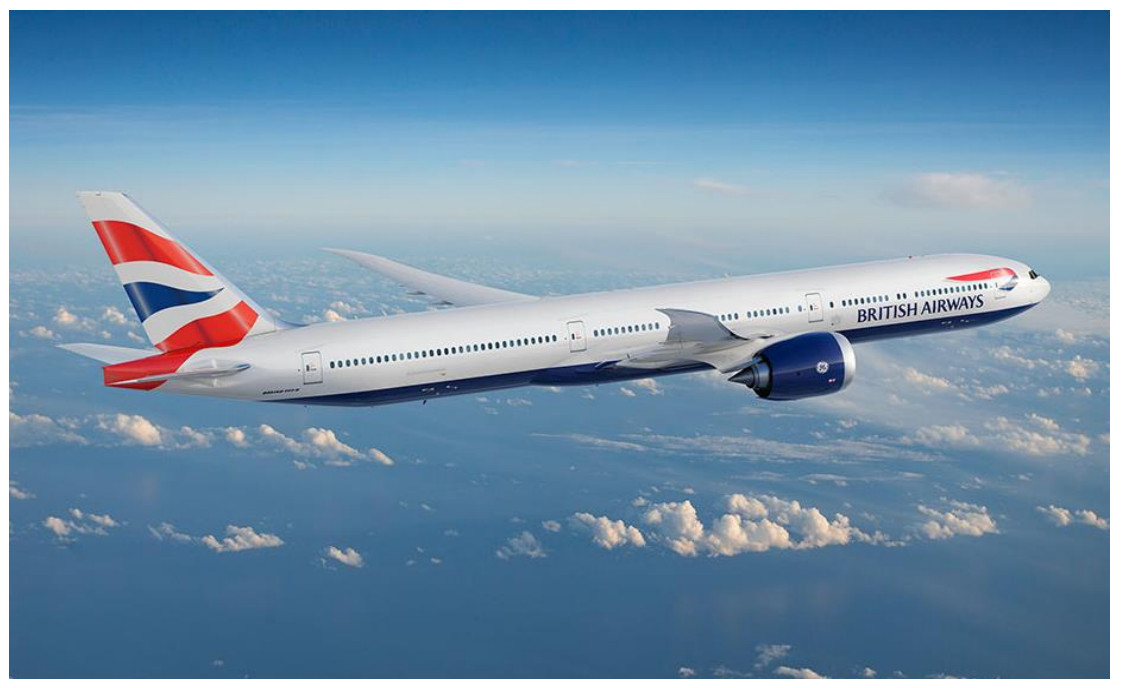

Fig. 1: The Boeing 777-9 
The aircraft also uses classic technologies - such as the classic jump, unlike the Airbus models that have switched to joysticks. Similarly, the front section (section 41) is identical to that of the Boeing 767.

For the comfort of pilots and crew members over long distances, there is a special resting space above the passenger cabin, complete with beds. In fact, the entire interior of the plane was new and then used in other models.

The plane was designed to provide three markets depending on the required distance to travel: A market (3900-5200 nautical miles - 7223-9630 km), B market (5800-7700 nautical miles - 10742-14620 km) and C market (any over 8000 nautical miles - $14816 \mathrm{~km}$ ).

Thus, there are 5 passenger variants: 777-200, 777200ER (Extended Range), 777-200LR (Long Range), 777-300 and 777-300ER. In addition, a cargo model, called 777F (Freighter - Freight), is also available.

The 777-200 (sometimes 772A): Built for Market A, was first delivered in 1995 with United Airlines. The maximum take-off mass is 229-247 tons and the range is 3.780-5.150 nautical miles $(7,000-9,500 \mathrm{~km})$. It is available with three engine models: $329 \mathrm{kN}$ Pratt and Whitney PW4074 at $329 \mathrm{kN}, \mathrm{GE} 90-75 \mathrm{~B}$ at $334 \mathrm{kN}$, or Rolls Royce Trent 875s, also at 334 kN. 88 777-200 aircraft were ordered, all delivered. The competition is the Airbus A330.

777-200ER (sometimes 772B): It was the initial offer for the B market, with a larger authorized mass (263-286 t), additional fuel tanks and increased autonomy of between 11,000 and 14,300 km. The first model was delivered in 1997 to British Airways. The model holds the single-engine flight record - sailed for $192 \mathrm{~min}$ (maximum ETOPS limit at that time) on March 17, 2003, with 255 passengers on board, over the Pacific Ocean, then landing safely. There were ordered 430 airplanes, of which 395 were already delivered. The competition is the Airbus A340-300.

The 777-200LR is the latest Boeing 777 - launched in 2006. It is the world's largest autonomous airplane capable of connecting almost any two airports in the world - the plane can fly $17446 \mathrm{~km}$ without stopping in 18 hours. It uses GE90-110B1 engines of $495 \mathrm{kN}$ and has even more fuel tanks. Holds the record for flying a commercial jet, flying $21.602 \mathrm{~km}$, from Hong Kong to London in 22 hours (the long route, the east, above the Pacific, America and the Atlantic normal route, to the west, it is much shorter, being daily traveled by several models). Currently, there are 40 models ordered, of which 2 have already been delivered to Pakistan International Airlines and one to Air Canada. Boeing works to be increased even more aircraft autonomy (and to compete with the future Airbus A350), so LondonSydney, one of the last routes that cannot be offered nonstop become possible. Currently, he does not have a competitor (Airbus A340-500 is the closest model but only has a lower range and four engines).

The 777-300 is the long-haul model for the A-Series and was also sold as a replacement for the original Boeing 747 models that had reached the end of their life. It is longer with $10.1 \mathrm{~m}$, allowing up to 550 passengers in the charter configuration (in the standard configuration, three classes, the capacity is 368 passengers, with a $10,500 \mathrm{~km}$ autonomy. It is capable of ETOPS-180 and employs $400 \mathrm{kN}$ of Pratt and Whitney (PW4090) or $436 \mathrm{kN}$ General Electric GE90-92Bs. 60 pieces were ordered, all of which were delivered - the last command was held in 2002, the model being replaced by 777-300ER. Airbus A340-300 and Airbus A340-600 are competing models.

The 777-300ER is the top-of-the-range model, offering a 777-300 range and a greater range - nearly $14,594 \mathrm{~km}$. This is possible due to GE90-115B engines, larger authorized masses and structural improvements that allow more fuel to be transported under similar passenger and freight conditions. The 777-300ER flew over $6 \mathrm{~h}$ with a single engine for ETOPS certification (although only $3 \mathrm{~h}$ of flight was required); 266 pieces were ordered from which 89 pieces were delivered.

The cargo model is built from a mix of 777-300ER (landing gear, tank) and 777-200LR (engines and structure). The first flight will take place in 2008 and will be able to carry nearly 103 tons over a distance of $9065 \mathrm{~km}$.

\section{Results}

Flight 38 of British Airways was a flight that left Beijing Airport to Heathrow.pe airport on January 18, 2008, a Boeing 777-200er plane that served the flight lost both engines. The Avion planted 1 minute after that crashed on the runway. Of the 153 passengers, 47 were injured. The loss of engines was the ice from the fuel. The Avion was the first Boeing 777 thrown into the old iron.

Asiana Airlines flight 214 was a passenger transpacific flight operated by Asiana Airlines, which left Shanghai Pudong International Airport, to stop at Incheon International Airport near Seoul, South Korea, to the destination of San Francisco International Airport the county of San Mateo, California, USA. On July 6, 2013, a Boeing 777-200ER aircraft serving the flight missed the landing on San Francisco International Airport, with 291 passengers and 16 crew members aboard. Among the passengers, there were 141 Chinese citizens, 77 Korean citizens and 61 American citizens.

This was the first fatal accident involving a 777 model, three people losing their lives after the incident, but only two people from strict aviation accident (the third person (life after the impact of the plane and track) was hit by a fireman's car causing death). 
Another incident is underway (08/03/2014) and involved a Boeing 777-200ER that took off from Kuala Lumpur with 239 people aboard, of which 227 passengers of 13 nationalities and 12 crew members and had to arrives in Beijing at 06.30 (00.30, Romanian time). At the time of writing, the plane was not declared as collapsing, but the Vietnamese navy has already found along $\sim 15 \mathrm{~km}$ of fuel in the South China Sea.

The worst incident was on July 17, 2014, when a 777-200ER Boeing aircraft was shot down 4 hours after Amsterdam left Schipol Airport to Kuala Lumpur. 298 passengers lost their lives. The 17-year-old 9M-MRD aircraft had its first flight on 17 July 1997, 17 years from the disaster.

\section{Discussion}

In the early 1930s, Boeing became a leader in aircraft construction and the design revolution that set the road for other tokens in the 1930s. In 1930, Monorail, a small monoplane wing carrying the mail, was built. Built entirely of metal, it was very fast and aerodynamic and had a retractable landing system. In fact, his design was so revolutionary that the engines and propellers of the time were not suited to realize the potential of the plane. Until the development of the propellers, Boeing built the Model 247 aircraft.

Two monorails were built. The second, model 221 had a cabin with six passengers. In 1931, Monomail design became the foundation of Boeing YB-9, the first monoplane bomber with golden console wings. Five examples came into operation between September 1932 and March 1933. The performance of the two-engine monoplane bomber led to a reconsideration of air defense requirements, although it was soon overcome by fast-moving bombers.

In 1932, Boeing introduced model 248, the world's first monoplane fighter. The P-26 Peashooter was in the front line with the US Air Force Corps from 1934 to 1938.

In 1933, the Boeing 247 was introduced, which set the standard for all competitors in the passenger transport market. The 247 was a completely metallic monoplane, much faster, safer and easier to remove than other passenger planes. For example, it was the first twoengine passenger plane to fly on an engine. In an era of insecure engines, this flight safety has been greatly improved. Boeing has built the first 59 aircraft exclusively for its own subsidiary operations of United Airlines. This severely affected competing airlines and was typical of the corporate anti-competitive behavior that the US government wanted to ban at the time. The direction established with the 247 was further developed by Douglas Aircraft, resulting in one of the most successful models in aviation history.

The Air Mail Act of 1934 banned airlines and manufacturers from being under the same corporate umbrella, so the company split into three smaller companies - Boeing Airplane Company, United Airlines and United Aircraft Corporation, the precursor United Technologies. Boeing retained the Stearman facilities in Wichita, Kansas. After splitting United Aircraft, William Boeing sold his shares and left Boeing. Clairmont "Claire" L. Egtvedt, who became Boeing's president in 1933, became president. He believed that the future of the company was building larger planes. The works began in 1936 on Boeing Plant 2 to fit the production of older modern aircraft.

From 1934 to 1937, Boeing developed a long-range experimental bomber, the XB-15. Since its introduction in 1937, it has been the largest craft harder than the air it has built so far. Attempts have shown that its speed has been unsatisfactory, but the design experience has been used to develop the 314 model that followed a year later.

Overlapping the YB-15 development period, Pan American World Airways (Pan Am) has reached an agreement to develop and build a commercial boat to transport passengers on the Transcaucasian routes. The first flight of Boeing 314 Clipper was in June 1938. It was the largest civilian aircraft of the day, with a capacity of 90 passengers a day and 40 passengers on night flights. A year later, the first regular American passenger service was inaugurated. in Great Britain. Subsequently, other routes were opened, so Pan Am flew with Boeing 314 soon to destinations around the world.

In 1938, Boeing finished his work at Stratoliner 307. It was the first cabin airplane in the world and was able to navigate at an altitude of $6,100 \mathrm{~m}$, in most weather conditions. It was based on the B-17, using the same wings, tail and motors.

During the Second World War, Boeing built a large number of B-17 and B-29 bombers (Boeing ranks 12th among US companies in the value of wartime production contracts). Many of the workers were women whose husbands went to war. At the beginning of March 1944, production increased, so that each month more than 350 planes were built. To prevent an air attack, the production plants were covered with greenery and agricultural land. During the war, US airlines have cooperated. Boeing Booming B-17 was also assembled by Lockheed Aircraft Corp and Douglas Aircraft Co., while the B-29 was also assembled by Bell Aircraft Co. and by Glenn L. Martin. In 1942, Boeing began developing the C-97 Stratofreighter, the first in a generation of heavy military transport; came into operation in 1947. The C-97 was successfully adapted to be used as a fuel tank, although its transport role was soon limited by models that had advantages either in versatility or capacity.

After the war, most bombing orders were canceled and 70,000 people lost their Boeing job. The company wanted to recover quickly by selling the Stratocruiser (model 377), a four-engine luxury commercial aircraft derived from the C-97. However, sales of this model 
were not as expected and Boeing had to look for other opportunities to overcome the situation. In 1947, Boeing flew his first aircraft, XB-47, where B-47 and B-52 bombers were successful.

Boeing has developed military planes such as B-47 Stratojet bombers and B-52 Stratofortress in the late 1940s and 1950s. In the early 1950s, Boeing used the company's funds to develop a 367-80 number that led to the KC- 135 Stratotanker and Boeing 707. Some of these were built at the Boeing facilities in Wichita, Kansas, which existed between 1931 and 2014.

Between the last delivery of 377 in 1950 and the first order for 707 in 1955, Boeing was stopped by the commercial aviation market.

In the mid-1950s, technology advances significantly, giving Boeing the opportunity to develop and produce new products. One of the first was the short-range missile used to intercept the enemy plane. Until then, the cold war had become a fact of life and Boeing used its short-range missile technology to develop and build an intercontinental missile.

In 1958, Boeing began transporting 707, the first commercial airplane in the United States, in response to British Comet De Havilland, French Caravelle and Tupolev Tu-104 Soviet, which were the first commercial airplanes in the world. With the 707, a four-engined airplane and 156 passengers, the US has become the leader in commercial token production. A few years later, Boeing added a second version of this aircraft, the Boeing 720 , which was slightly faster and had a shorter range.

Boeing was an important engine manufacturer for turbines in the 1950s and 1960s. Engines were one of the company's major efforts to expand its product base beyond military aircraft after the Second World War. Turbines with gas turbines started in 1943 and Boeing turbines were designated 502 (T50), 520 (T60), 540, 551 and 553. Boeing built 2461 engines before production began in April 1968 Many Boeing engine applications, with the boat.

Vertol Aircraft Corporation was acquired by Boeing in 1960 and was reorganized as a Boeing Vertol division. Chinook CH-47 with two wheels, produced by Vertol, took the first flight in 1961. This helicopter with heavy lifts remains a vehicle with jobs so far. In 1964, Vertol also began production of the $\mathrm{CH}-46$ Sea Knight.

In December 1960, Boeing announced the 727 jetliner model, which entered the commercial service about three years later. The various variants of passengers, freight wagons and convertible wagons were developed for the 727 model. 727 was the first commercial jetliner to reach 1,000 sales.

On May 21, 1961, the company reduced its name to the current "Boeing Company".

Boeing won a contract in 1961 for manufacturing the S-IC stage of the Saturn V rocket, manufactured at Michoud's installation in New Orleans, Louisiana.
In 1966, Boeing President William M. Allen asked Malcolm T. Stamper to launch the production of the new 747 planes he proposed the future of the company. It was a challenge and monumental management and included building the largest factory in the world to build 747 at Everett, Washington, a factory that has the size of 40 football fields.

In 1967, Boeing introduced another short- and medium-range aircraft, the 737 engine. Since then, it has become the commercial airliner with the best-selling commercial airliner in aviation history. Several versions have been developed, mainly to enhance the capacity and range of seats; The 737 remains in production from February 2018, with the latest 737 MAX series.

The launch of ceremonies for the first 747-100 took place in 1968 at the new massive factory in Everett, about an hour's drive from Seattle's Boeing House. The aircraft made its first flight a year later. The first commercial flight took place in 1970. The 747 has an intercontinental range and a higher seating capacity than Boeing's previous aircraft.

Boeing also developed hydrophones in the 1960s. USS High Point (PCH-1) was a submarine experimental hunter. USS Tucumcari Patrol Hydrophore (PGH-2) was more successful. Only one was built but saw service in Vietnam and Europe before collapsing in 1972. Water-jet waterproofing and submerged flyers were examples of the latest Pegasus Nursery and Patrol Hydrofoils 929 Jetfoil in the 1980s Tucumcari and Ships Later they were produced in Renton. While hydrophore vessels were closed in the late 1980s, Boeing Jetfoils are still in service in Asia.

In the early 1970s, Boeing suffered a simultaneous decrease in Vietnam's military spending, the slowdown in the space program, such as the Apollo project, the 1969-1970 recession and the \$2 billion company's debt, building the new 747 aircraft. Boeing has not received orders for more than a year. The best thing for the future, the 747, was delayed in production for three months due to problems with the Pratt and Whitney engines. Then, in March 1971, Congress voted to suspend the funding for the development of the Boeing 2707 Supersonic (SST), the US response to the BritishFrench Concorde, forcing the end of the project.

The commercial aircraft group, by far the largest Boeing unit, moved from 83,700 employees in 1968 to 20,750 in 1971. Each unpaid Boeing employee cost at least one job in Seattle and the unemployment rate increased to $14 \%$. Population vacancy rates rose to $16 \%$, from $1 \%$ in 1967.

In January 1970 , the first 747 , a four-engine longrange aircraft, flew its first commercial flight to Pan American World Airways. The 747 has changed the aerospace industry, offering a much higher capacity than any other production aircraft. The company delivered more than 1,500 Boeing 747 engines. The 747 product 
has undergone continuous improvement to keep it up-todate. Larger versions have also been developed by stretching the upper deck. The latest version of 747, 7478 , has been in production since 2018 .

Boeing launched three Jetfoil 929-100 hydrophones purchased in 1975 for service in the Hawaiian Islands. When the service ended in 1979, the three hydrophones were acquired by Far East Hydrofoil for service between Hong Kong and Macao.

In the 1970s, Boeing also developed the US Light Light Rail vehicle, which was used in San Francisco, Boston and Morgantown, West Virginia.

In 1983, the economic situation began to improve. Boeing has collected 1,000 passenger planes. In the following years, commercial aircraft and military versions became the basic equipment of airlines and air forces. As passenger air traffic increased, the competition was more difficult, especially from Airbus, a new European entrant in commercial aircraft production. Boeing had to provide new aircraft and developed a single 757 , the largest unidirectional corridor 767 and improved versions of 737. An important project of these years was the space shuttle, to which Boeing contributed with its experience in the spacecraft purchased in the Apollo period. Boeing also participated with other products in the space program and was the first contractor of the International Space Station Program.

Over the decade, several military projects have entered production, including Boeing's support for the B2 stealth bomber. As part of a Northrop-led industrial team, Boeing built the exterior of the B-2, the center of the puppy's central fuselage, the landing system, the fuel supply system and the weapon delivery system. At its peak in 1991, the B-2 was Boeing's largest military program, which hired about 10,000 people. In the same year, the US National Aeronautics Association awarded the B-2 Colli Trophy the largest aerospace achievement in America. The first B-2 came out of the final assembly plant of the bomber in Palmdale, California in November 1988 and flew for the first time on July 17, 1989.

The air defense system against airplanes and a new generation of short-range missiles have also entered production. During these years, Boeing has been very active in modernizing existing military equipment and developing new ones. Boeing has also contributed to the development of wind energy with MOD-2 experimental wind turbines for NASA and the United States Department of Energy and MOD-5B for Hawaii.

Boeing was one of the seven companies that fought for the advanced tactical fighter. Boeing agreed with General Dynamics and Lockheed for all three companies to participate in the development if one of the three companies was selected. The Lockheed design was finally selected and developed in the F-22 Raptor.

In April 1994, Boeing presented the most modern commercial aircraft, the 777 engine, with a capacity of approximately 300-370 passengers in a typical three seater seat between 767 and 747. The longest aircraft with two engines at sea 777 a, was the first Boeing to have a cable system and was designed in part to meet the challenges posed by the European Airbus on Boeing's traditional market. This aircraft has reached an important milestone being the first aircraft to have been fully engineered by Computer-Aided Design (CAD) techniques. The 777 was also the first airplane to be certified for the 180-minute ETOPS at FAA commissioning. Also in the mid-1990s, the company developed the revised version of the 737 , known as 737 "Next-Generation" or 737NG. Since then, it has become the fastest selling option in 737 histories and on April 20, 2006, sales have passed those of the "Classic 737" with a subsequent order for 79 Southwest Airlines.

In 1995, Boeing chose to demolish the headquarters complex on East Marginal Way South instead of updating it to fit new seismic standards. The headquarters were moved to an adjacent building and the plant was demolished in 1996. In 1997, Boeing relied on East Marginal Way South at King County Airport in Seattle.

In 1996, Boeing acquired Rockwell's aerospace and defense units. Rockwell Business Units have become a Boeing subsidiary, named Boeing North American, Inc. In August 1997, Boeing merged with McDonnell Douglas in a \$ 13 billion swap and Boeing was the surviving company. After the merger, McDonnell Douglas MD-95 was renamed Boeing 717 and tri-jet MD-11 production was limited to merchandise. Boeing introduced a new corporate identity with the completion of the merger, incorporating the Boeing logo and a stylized version of the McDonnell Douglas symbol, which was derived from the Douglas Aircraft logo of the 1970s.

An aerospace analyst criticized the chief executive and his deputy, Philip M. Condit and Harry Stonecipher because they first thought of their personal benefits and caused Boeing's problems many years later. Instead of investing a large cash reserve to build new planes, they have launched a program to buy Boeing shares for more than $\$ 10$ billion.

In May 1999, Boeing studied the acquisition from Embraer to encourage the community between E-Jets and Boeing 717 but was set by US President Harry Stonecipher. He preferred to buy Bombardier Aerospace, but his owner, the Beaudoin family, asked too much for Boeing, who remembered buying Havilland Canada in the 1980s, losing a million dollars a day three years earlier to sells Bombardier 1992.

In January 2000, Boeing chose to expand its presence in another satellite communications sector by acquiring Hughes Electronics. Hughes Space and Communications, which pioneered satellite communications.

In September 2001, Boeing moved Seattle to Chicago. Chicago, Dallas and Denver - who were struggling to become the new home of the largest aerospace concern in 
the world - offered millions of dollars. Its offices are located in the Fulton River District just off Chicago.

On October 10, 2001, Boeing lost his rival, Lockheed Martin, to tens of billions of dollars in the Joint Strike Fighter. Boeing's entry, X-32, was rejected in favor of Lockheed X-35's participant. Boeing continued to serve as the main contractor at the International Space Station and built some of the major components.

Boeing began to develop the KC-767 fuel tank in the early 2000s. Italy and Japan have ordered four KC-767s. After FAA delays and certifications, Boeing delivered tanks to Japan in 2008, followed by the second $\mathrm{KC}-767$ on March 5, 2010. Italy received four KC-767 in 2011.

In 2004, Boeing finished production of 757 after 1050 aircraft were produced. The more advanced versions of the 737 began competing against the 757 and the planned 787-3 plan was to fill most of the 757 markets. In the same year, Boeing announced that model 717 , the newest civil aircraft, McDonnell Douglas, will begin production in 2006. 767 was also in danger of canceling the replacement of 787 but ordered the extended load schedule.

After several decades of success, Boeing lost ground to Airbus and subsequently lost its leading position in the aircraft market in 2003. The multiple Boeing projects were tracked and then canceled, especially the Sonic Cruiser, a proposed jetliner to travel with the speed of sound, reducing intercontinental travel by up to $20 \%$. It was launched in 2001 with a new campaign to promote the new motto of Forever New Frontiers and redefine its image. However, the fate of the plane was sealed by changes in the commercial aviation market after the Sept. 11 attacks and by the poorer economy and rising fuel prices.

Later, Boeing optimized his production and turned his attention to a new Boeing 787 Dreamliner, using much of the technology developed for the Sonic Cruiser, but in a more conventional aircraft designed for maximum efficiency. The company also launched new variants of its successful 737 and 777 models. The 787 proved to be a very popular choice for airlines and earned a record number of orders before launch. With delays in the Airbus A380 program, several airlines have threatened to change the A380 orders in the new 747-8 version of Boeing. The Airbus response to the 787, A350, received a warm response at the start when it was announced as an enhanced version of the A330 and then received important commands when Airbus promised a completely new design. The 787 programs encountered delays, the first flight did not take place until the end of 2009.

After regulatory approval, Boeing created a joint venture, the United Launch Alliance with its competitor, Lockheed Martin, on December 1, 2006. The new association is the largest provider of missile launch services to the US government.
In 2005, former Boeing CEO Gary Scott and then CEO of Bombardier CSeries suggested collaboration for future CSeries, but an internal study embraced Embraer as the best partner for regional jets. The Brazilian government wanted to keep control and blocked a purchase.

On August 2, 2005, Boeing sold the Rocketdyne rocket engines division to Pratt and Whitney. On May 1, 2006, Boeing agreed to buy Dallas, Aviall, Inc. in Texas for $\$ 1.7$ billion and keep $\$ 350$ million in debt. Aviall, Inc. and its subsidiaries, Aviall Services, Inc. and ILS formed a wholly-owned subsidiary of Boeing Commercial Aviation Services (BCAS).

On August 2, 2005, Boeing sold the Rocketdyne rocket engines division to Pratt and Whitney. On May 1, 2006, Boeing agreed to buy Dallas, Aviall, Inc. in Texas for $\$ 1.7$ billion and keep $\$ 350$ million in debt. Aviall, Inc. and its subsidiaries, Aviall Services, Inc. and ILS formed a wholly-owned subsidiary of Boeing Commercial Aviation Services (BCAS).

Realizing that an increasing number of passengers relied on their computers to stay in touch, Boeing introduced Connexion by Boeing, a satellite-based satellite service that promised air travelers unprecedented access to the World Wide Web. The company started in 2005 with journalists, receiving generally favorable reviews. However, in the face of competition from cheaper options, such as cellular networks, it turned out to be too difficult to sell to most airlines. In August 2006, after a short and unsuccessful search of a business buyer, Boeing opted for service discontinuation.

On August 18, 2007, NASA selected Boeing as a contractor for the Ares I Scene rocket launcher, based on Apollo-Saturn and Space Shuttle technologies, built at the NASA Michoud Assembly near New Orleans; Boeing built the S-IC station of the Saturn V rocket in this place in the 1960s.

Boeing launched the 777 Freighter in May 2005 with an order from Air France. The transport variant is based on the -200LR model. Other clients include FedEx and Emirates. Boeing officially announced in November 2005 that it will produce a larger version of the $747,747-8$, in two variants, starting with the Freighter version with firm orders for two freight carriers. The second version, called Intercontinental, is for airlines. Both versions 747-8 have a protruding fuselage, advanced engine and wing and include other technologies developed for the 787 .

Boeing also received the launch contract from the US Navy for the P-8 Poseidon Multimission Maritime Aircraft, an anti-submarine patrol war aircraft. He also received orders for 737 AEW\&C "Wedgetail". The company also introduced new versions with an extended range of 737 . These include the 737-700ER and 737900ER models. The 737-900ER is the newest and will expand the range 737-900 in a range similar to that of the $737-800$, with the capacity to cover more passengers due to the addition of two additional emergency exits. 
777-200LL Worldliner has embarked on a wellknown global demonstration tour in the second half of 2005, demonstrating its ability to fly farther than any other commercial aircraft. On November 10, 2005, the 777-200LR established a world record for the longest non-stop flight.

The plane, who left Hong Kong, traveled to London, made a longer route, including flying over the US. He flew 11,664 nautical miles $(21,601 \mathrm{~km})$ during the $42 \mathrm{~h}$ flight of $22 \mathrm{~h}$. She was led by Pakistan International Airlines pilots and PIA was the first plane to fly on 777200LL Worldliner.

On August 11, 2006, Boeing agreed to form a joint venture with the large titanium manufacturer in Russia, VSMPO-Avisma, for processing titanium forges. The forgings will be used on the 787 programs. In December 2007, Boeing and VSMPO-Avisma created a joint venture, Ural Boeing Manufacturing and signed a titanium agreement by 2015 and Boeing plans to invest $\$$ 27 billion in Russia over the next 30 years.

In February 2011, Boeing received a contract for 179 CP-46 US Air Force Tanks worth 35 billion dollars. The $\mathrm{KC}-46$ is based on the $\mathrm{KC}-767$.

In May 2006, four conceptual models examined by Boeing were presented in The Seattle Times on the basis of the company's internal documents. The research targets two directions: Low-cost planes and ecological planes. Codenamed by the Muppets family, a design team known as the Green Team focused primarily on reducing fuel consumption. All four models illustrate the look of the rear engine.

"Fozzie" uses open rotors and offers a lower cruise speed.

The "Cup" has very thin, long wings with the ability to partially fold to facilitate movement.

"Kermit Kruiser" has front-facing wings, over which the engines are positioned to reduce the low noise due to the ascending signing of the escape signature.

"Honeydew" with the delta wing design, resembles a marriage of the wing concept and the traditional tube fuselage.

As with most concepts, these models are only in the exploration phase, designed to help Boeing assess the potential of such radical technologies.

Boeing has recently patented field intensity technology, also known as the shock wave attenuation system, which would protect vehicles against shock waves generated by nearby explosions. Boeing has not yet confirmed when he plans to build and test the technology.

In the summer of 2010, Boeing acquired Fairfax, based on VA C4ISR and the developer of the Argon ST combat system, to expand its C4ISR cybernetic and intelligent capabilities.

In 2011, Boeing was reluctant to reconsider the 737 or develop a new small aircraft for which Embraer could have been involved, but when the A320neo was launched with new engines, it precipitated the 737 MAX. On November 17, Boeing received the largest \$ 21.7 billion in Indonesian Lion Air LCC for 201,737 MAX, 29,737-900ER and 150 purchase days after the previous $\$ 18$ billion for Emirates 50,777-300ER.

On January 5, 2012, Boeing announced that it would close the factory in Wichita, Kansas, with 2160 workers before 2014, more than 80 years from its inception, employing up to 40,000 people.

In May 2013, Boeing announced it will reduce to 1,500 IT jobs in Seattle over the next three years through layoffs, losses and especially relocations in St. Louis and North Charleston, South Carolina - 600 jobs each. In September, Boeing announced that their installation in Long Beach, the C-17 Globemaster III military transport, will be closed.

In January 2014, the company announced profits of \$ 1.23 billion for Q4 2013, a 26\% increase due to higher demand for commercial aircraft. The last aircraft to be served at Boeing Wichita Station left in May 2014.

In September 2014, NASA awarded Boeing and SpaceX contracts for the transport of astronauts to the International Space Station.

In June 2015, Boeing announced that James McNerney would resign as CEO to be replaced by Boeing Dennis Muilenburg's COO on July 1, 2015. The 279th and the last C-17 were delivered before the closure, affecting 2,200 jobs.

In February 2016, Boeing announced that Boeing Chairman and CEO, Dennis Muilenburg, was elected as the 10th President of the Council, after James McNerney.

In March, Boeing announced plans to cut up to 4,000 jobs in the airline business division by mid-year. On May 13, 2016, Boeing opened a 27-acre factory in Washington, which will produce composite carbon wings for the Boeing 777X to be shipped from 2020 .

On April 28, 2016, Bombardier Aerospace sold 75 CSeries CS100 firmly plus 50 options for Delta Air Lines. On April 27, 2017, Boeing filed a dumping claim for each of them, at a price of $\$ 19.6$ million, below the cost of production of $\$ 33.2$ million.

On June 9, 2017, the International Commerce Commission (USITC) found that US industry could be threatened. On September 26, the United States Department of Commerce (DoC) has noticed 220\% of subsidies and will collect deposits based on them.

It will add a preliminary anti-dumping duty of $80 \%$, resulting in a total charge of $300 \%$.

DoC announced the final ruling, a total charge of $292 \%$, on December 20th. On January 10, 2018, the Canadian government lodged a complaint with the World Trade Organization against the United States.

On January 26, 2018, the four USITC Commissioners unanimously agreed that the US industry is not threatened and that no pass orders will be issued to overturn the taxes imposed. The Commission's public report was made available by February 2018. On March 22 , Boeing refused to appeal the ruling. 
In October 2017, Boeing announced plans to acquire Aurora Flight Sciences to expand its capabilities to develop autonomous, long-distance and long-distance aircraft for commercial and military business, pending regulatory approval.

\section{Conclusions}

British Airways is ordering up to 42 Boeing 777-9s to modernize the UK flag-carrier's long-haul fleet.

Eighteen aircraft are firm orders, complemented by another 24 as options. The twinjets will be fitted with 325 seats in a four-class configuration.

BA parent IAG has disclosed the decision 28 (February, 2019 SOURCE: Flight Dashboard by: David Kaminski-Morrow London).

It says the 777-9s will be used to replace 14 Boeing 747$400 \mathrm{~s}$ as well as four 777-200s over the course of 2022-25.

All the 777-9s will be powered by General Electric GE9X engines and the agreement includes a "comprehensive" support package, says IAG.

IAG chief executive Willie Walsh says the 777-9 is the "ideal replacement" for the 747 .

\section{Acknowledgement}

The work was appreciated by teams of professors from the departments of automobiles from several universities in Romania and Italy. This text was acknowledged and appreciated by Associate Professor Aniello Riccio SECONDA UNIVERSITA' DEGLI STUDI DI NAPOLI Italy, whom we thanks and in this way.

\section{Funding Information}

Research contract: Contract number 36-5-4D/1986 from 24IV1985, beneficiary CNST RO (Romanian National Center for Science and Technology) Improving dynamic mechanisms internal combustion engines. All these matters are copyrighted. Copyrights: 548cgiywDssin, from: 22-04-2010, 08:48:48.

\section{Ethics}

Author declares that are not ethical issues that may arise after the publication of this manuscript. This article is original and contains unpublished material.

\section{References}

Ab-Rahman, M.S., H. Guna, MH. Harun, SD. Zan and K. Jumari, 2009. Cost-effective fabrication of selfmade $1 \times 12$ polymer optical fiber-based optical splitters for automotive application. Am. J. Eng. Applied Sci., 2: 252-259.

DOI: 10.3844/ajeassp.2009.252.259
Abam, F.I., I.U. Ugot and D.I. Igbong, 2012. Performance analysis and components irreversibilities of a (25 MW) gas turbine power plant modeled with a spray cooler. Am. J. Eng. Applied Sci., 5: 35-41.

DOI: 10.3844/ajeassp.2012.35.41

Abdelkrim, H., S.B. Othman, A.K.B. Salem and S.B. Saoud, 2012. Dynamic partial reconfiguration contribution on system on programmable chip architecture for motor drive implementation. Am. J. Eng. Applied Sci., 5: 15-24.

DOI: 10.3844/ajeassp.2012.15.24

Abdullah, M.Z., A. Saat and Z. Hamzah, 2011. Optimization of energy dispersive $\mathrm{x}$-ray fluorescence spectrometer to analyze heavy metals in moss samples. Am. J. Eng. Applied Sci., 4: 355-362. DOI: 10.3844 /ajeassp.2011.355.362

Abdullah, M., A. F.M. Zain, Y. H. Ho and S. Abdullah, 2009. TEC and scintillation study of equatorial ionosphere: A month campaign over sipitang and parit raja stations, Malaysia. Am. J. Eng. Applied Sci., 2: 44-49. DOI: 10.3844/ajeassp.2009.44.49

Abdullah, H. and S.A. Halim, 2009. Electrical and magnetoresistive studies $\mathrm{Nd}$ doped on $\mathrm{La}-\mathrm{Ba}-\mathrm{Mn}-\mathrm{O}_{3}$ manganites for low-field sensor application. Am. J. Eng. Applied Sci., 2: 297-303.

DOI: 10.3844/ajeassp.2009.297.303

Abouobaida, H., 2016. Robust and efficient controller to design a standalone source supplied DC and AC load powered by photovoltaic generator. Am. J. Eng. Applied Sci., 9: 894-901.

DOI: 10.3844/ajeassp.2016.894.901

Abu-Ein, S., 2009. Numerical and analytical study of exhaust gases flow in porous media with applications to diesel particulate filters. Am. J. Eng. Applied Sci., 2: 70-75.

DOI: 10.3844/ajeassp.2009.70.75

Abu-Lebdeh, T.M., G. Pérez-de León, S.A. Hamoush, R.D. Seals and V.E. Lamberti, 2016. Gas atomization of molten metal: Part II. Applications. Am. J. Eng. Applied Sci., 9: 334-349.

DOI: 10.3844/ajeassp.2016.334.349

Agarwala, S., 2016. A perspective on 3D bioprinting technology: Present and future. Am. J. Eng. Applied Sci., 9: 985-990.

DOI: 10.3844/ajeassp.2016.985.990

Ahmed, M., R. Khan, M. Billah and S. Farhana, 2010. A novel navigation algorithm for hexagonal hexapod robot. Am. J. Eng. Applied Sci., 3: 320-327. DOI: 10.3844/ajeassp.2010.320.327

Ahmed, R., M. Khan, H. Haque and H. Rahman, 2016. An approach to develop a dynamic job shop scheduling by fuzzy rule-based system and comparative study with the traditional priority rules. Am. J. Eng. Applied Sci., 9: 202-212. DOI: 10.3844/ajeassp.2016.202.212 
Akhesmeh, S., N. Pourmahmoud and H. Sedgi, 2008. Numerical study of the temperature separation in the ranque-hilsch vortex tube. Am. J. Eng. Applied Sci., 1: 181-187. DOI: 10.3844/ajeassp.2008.181.187

Al-Abbas, I.K., 2009. Reduced order models of a current source inverter induction motor drive. Am. J. Eng. Applied Sci., 2: 39-43.

DOI: 10.3844/ajeassp.2009.39.43

Al-Hasan, M.I. and A.S. Al-Ghamdi, 2016. Energy balance for a diesel engine operates on a pure biodiesel, diesel fuel and biodiesel-diesel blends. Am. J. Eng. Applied Sci., 9: 458-465. DOI: 10.3844/ajeassp.2016.458.465

Al Smadi, T.A., 2011. Low cost smart sensor design. Am. J. Eng. Applied Sci., 4: 162-168.

DOI: 10.3844/ajeassp.2011.162.168

AL Qadi, A.N.S., M.B.A. ALhasanat, A. AL Dahamsheh and S. AL Zaiydneen, 2016a. Using of box-benken method to predict the compressive strength of selfcompacting concrete containing Wadi Musa Bentonite, Jordan. Am. J. Eng. Applied Sci., 9: 406-411.

DOI: 10.3844/ajeassp.2016.406.411

Al Qadi, A.N.S., M.B.A. Alhasanat and M. Haddad, 2016b. Effect of crumb rubber as coarse and fine aggregates on the properties of asphalt concrete. Am. J. Eng. Applied Sci., 9: 558-564.

DOI: 10.3844/ajeassp.2016.558.564

Aleksic, S. and A. Lovric, 2011. Energy consumption and environmental implications of wired access networks. Am. J. Eng. Applied Sci., 4: 531-539. DOI: 10.3844/ajeassp.2011.531.539

Alhasanat, M.B., A.N. Al Qadi, O.A. Al Khashman and A. Dahamsheh, 2016. Scanning electron microscopic evaluation of self-compacting concrete spalling at elevated temperatures. Am. J. Eng. Applied Sci., 9: 119-127. DOI: 10.3844/ajeassp.2016.119.127

Ali, K.S. and J.L. Shumaker, 2013. Hardware in the loop simulator for multi-agent unmanned aerial vehicles environment. Am. J. Eng. Applied Sci., 6: 172-177. DOI: 10.3844/ajeassp.2013.172.177

Ali, G.A.M., O. Fouad and S.A. Makhlouf, 2016. Electrical properties of cobalt oxide/silica nanocomposites obtained by sol-gel technique. Am. J. Eng. Applied Sci., 9: 12-16. DOI: 10.3844/ajeassp.2016.12.16

Alwetaishi, M.S., 2016. Impact of building function on thermal comfort: A review paper. Am. J. Eng. Applied Sci., 9: 928-945. DOI: 10.3844/ajeassp.2016.928.945

Aly, W.M. and M.S. Abuelnasr, 2010. Electronic design automation using object oriented electronics. Am. J. Eng. Applied Sci., 3: 121-127.

DOI: 10.3844/ajeassp.2010.121.127

Amani, N., 2016. Design and implementation of optimum management system using cost evaluation and financial analysis for prevention of building failure. Am. J. Eng. Applied Sci., 9: 281-296.

DOI: 10.3844/ajeassp.2016.281.296
Anizan, S., K. Yusri, C.S. Leong, N. Amin and S. Zaidi et al., 2011. Effects of the contact resistivity variations of the screen-printed silicon solar cell. Am. J. Eng. Applied Sci., 4: 328-331. DOI: 10.3844/ajeassp.2011.328.331

Ascione, F., N. Bianco, R.F. De Masi, F. de Rossi and C. De Stasio et al., 2016. Energy audit of health care facilities: Dynamic simulation of energy performances and energy-oriented refurbishment of system and equipment for microclimatic control. Am. J. Eng. Applied Sci., 9: 814-834.

DOI: 10.3844/ajeassp.2016.814.834

Augustine, A., R.D. Prakash, R. Xavier and M.C. Parassery, 2016. Review of signal processing techniques for detection of power quality events. Am. J. Eng. Applied Sci., 9: 364-370.

DOI: 10.3844 /ajeassp.2016.364.370

Aversa, R., R.V.V. Petrescu, A. Apicella and F.I.T. Petrescu, 2017a. Nano-diamond hybrid materials for structural biomedical application. Am. J. Biochem. Biotechnol., 13: 34-41. DOI: $10.3844 / a j b b s p .2017 .34 .41$

Aversa, R., R.V. Petrescu, B. Akash, R.B. Bucinell and J.M. Corchado et al., 2017b. Kinematics and forces to a new model forging manipulator. Am. J. Applied Sci., 14: 60-80. DOI: 10.3844/ajassp.2017.60.80

Aversa, R., R.V. Petrescu, A. Apicella, I.T.F. Petrescu and J.K. Calautit et al., 2017c. Something about the V engines design. Am. J. Applied Sci., 14: 34-52. DOI: 10.3844 /ajassp.2017.34.52

Aversa, R., D. Parcesepe, R.V.V. Petrescu, F. Berto and G. Chen et al., 2017d. Process ability of bulk metallic glasses. Am. J. Applied Sci., 14: 294-301. DOI: 10.3844/ajassp.2017.294.301

Aversa, R., R.V.V. Petrescu, B. Akash, R.B. Bucinell and J.M. Corchado et al., 2017e. Something about the balancing of thermal motors. Am. J. Eng. Applied Sci., 10: 200.217. DOI: 10.3844/ajeassp.2017.200.217

Aversa, R., F.I.T. Petrescu, R.V. Petrescu and A. Apicella, 2016a. Biomimetic FEA bone modeling for customized hybrid biological prostheses development. Am. J. Applied Sci., 13: 1060-1067. DOI: 10.3844/ajassp.2016.1060.1067

Aversa, R., D. Parcesepe, R.V. Petrescu, G. Chen and F.I.T. Petrescu et al., 2016b. Glassy amorphous metal injection molded induced morphological defects. Am. J. Applied Sci., 13: 1476-1482. DOI: 10.3844/ajassp.2016.1476.1482

Aversa, R., R.V. Petrescu, F.I.T. Petrescu and A. Apicella, 2016c. Smart-factory: Optimization and process control of composite centrifuged pipes. Am. J. Applied Sci., 13: 1330-1341. DOI: 10.3844/ajassp.2016.1330.1341

Aversa, R., F. Tamburrino, R.V. Petrescu, F.I.T. Petrescu and M. Artur et al., 2016d. Biomechanically inspired shape memory effect machines driven by muscle like acting NiTi alloys. Am. J. Applied Sci., 13: 1264-1271. DOI: 10.3844/ajassp.2016.1264.1271 
Aversa, R., E.M. Buzea, R.V. Petrescu, A. Apicella and M. Neacsa et al., 2016e. Present a mechatronic system having able to determine the concentration of carotenoids. Am. J. Eng. Applied Sci., 9: 1106-1111. DOI: 10.3844/ajeassp.2016.1106.1111

Aversa, R., R.V. Petrescu, R. Sorrentino, F.I.T. Petrescu and A. Apicella, 2016f. Hybrid ceramo-polymeric nanocomposite for biomimetic scaffolds design and preparation. Am. J. Eng. Applied Sci., 9: 1096-1105. 10.3844/ajeassp.2016.1096.1105

Aversa, R., V. Perrotta, R.V. Petrescu, C. Misiano and F.I.T. Petrescu et al., 2016g. From structural colors to super-hydrophobicity and achromatic transparent protective coatings: Ion plating plasma assisted $\mathrm{TiO}_{2}$ and $\mathrm{SiO}_{2}$ Nano-film deposition. Am. J. Eng. Applied Sci., 9: 1037-1045.

DOI: 10.3844/ajeassp.2016.1037.1045

Aversa, R., R.V. Petrescu, F.I.T. Petrescu and A. Apicella, 2016h. Biomimetic and Evolutionary Design Driven Innovation in Sustainable Products Development. Am. J. Eng. Applied Sci., 9: 1027-1036. DOI: 10.3844/ajeassp.2016.1027.1036

Aversa, R., R.V. Petrescu, A. Apicella and F.I.T. Petrescu, 2016i. Mitochondria are naturally micro robots-a review. Am. J. Eng. Applied Sci., 9: 991-1002. DOI: 10.3844/ajeassp.2016.991.1002

Aversa, R., R.V. Petrescu, A. Apicella and F.I.T. Petrescu, 2016j. We are addicted to vitamins $\mathrm{C}$ and EA review. Am. J. Eng. Applied Sci., 9: 1003-1018. DOI: 10.3844/ajeassp.2016.1003.1018

Aversa, R., R.V. Petrescu, A. Apicella and F.I.T. Petrescu, 2016k. Physiologic human fluids and swelling behavior of hydrophilic biocompatible hybrid ceramopolymeric materials. Am. J. Eng. Applied Sci., 9: 962-972. DOI: 10.3844/ajeassp.2016.962.972

Aversa, R., R.V. Petrescu, A. Apicella and F.I.T. Petrescu, 20161. One can slow down the aging through antioxidants. Am. J. Eng. Applied Sci., 9: 1112-1126. DOI: 10.3844/ajeassp.2016.1112.1126

Aversa, R., R.V. Petrescu, A. Apicella and F.I.T. Petrescu, 2016m. About homeopathy or «Similia similibus curentur $\gg$. Am. J. Eng. Applied Sci., 9: 1164-1172. DOI: 10.3844/ajeassp.2016.1164.1172

Aversa, R., R.V. Petrescu, A. Apicella and F.I.T. Petrescu, 2016n. The basic elements of life's. Am. J. Eng. Applied Sci., 9: 1189-1197.

DOI: 10.3844/ajeassp.2016.1189.1197

Aversa, R., F.I.T. Petrescu, R.V. Petrescu and A. Apicella, 2016o. Flexible stem trabecular prostheses. Am. J. Eng. Applied Sci., 9: 1213-1221. DOI: 10.3844/ajeassp.2016.1213.1221

Babayemi, A.K., 2016. Thermodynamics, non-linear isotherms, statistical modeling and optimization of phosphorus adsorption from wastewater. Am. J. Eng. Applied Sci., 9: 1019-1026.

DOI: 10.3844/ajeassp.2016.1019.1026
Bakar, R.A., M.K. Mohammed and M.M. Rahman, 2009. Numerical study on the performance characteristics of hydrogen fueled port injection internal combustion engine. Am. J. Eng. Applied Sci., 2: 407-415. DOI: 10.3844/ajeassp.2009.407.415

Barone, G., A. Buonomano, C. Forzano and A. Palombo, 2016. WLHP systems in commercial buildings: A case study analysis based on a dynamic simulation approach. Am. J. Eng. Applied Sci., 9: 659-668. DOI: 10.3844/ajeassp.2016.659.668

Bedon, C., 2016. Review on the use of FRP composites for facades and building skins. Am. J. Eng. Applied Sci., 9: 713-723. DOI: $10.3844 /$ ajeassp.2016.713.723

Bedon, C. and C. Amadio, 2016. A unified approach for the shear buckling design of structural glass walls with non-ideal restraints. Am. J. Eng. Applied Sci., 9: 64-78. DOI: 10.3844/ajeassp.2016.64.78

Bedon, C. and C. Louter, 2016. Finite-element numerical simulation of the bending performance of posttensioned structural glass beams with adhesively bonded CFRP tendons. Am. J. Eng. Applied Sci., 9: 680-691. DOI: 10.3844/ajeassp.2016.680.691

Bolonkin, A., 2009a. Femtotechnology: Nuclear matter with fantastic properties. Am. J. Eng. Applied Sci., 2: 501-514. DOI: 10.3844/ajeassp.2009.501.514

Bolonkin, A., 2009b. Converting of matter to nuclear energy by ab-generator. Am. J. Eng. Applied Sci., 2: 683-693. DOI: 10.3844/ajeassp.2009.683.693

Boucetta, A., 2008. Vector control of a variable reluctance machine stator and rotor discs imbricates. Am. J. Eng. Applied Sci., 1: 260-265.

DOI: 10.3844/ajeassp.2008.260.265

Bucinell, R.B., 2016. Stochastic model for variable amplitude fatigue induced delamination growth in graphite/epoxy laminates. Am. J. Eng. Applied Sci., 9: 635-646. DOI: 10.3844/ajeassp.2016.635.646

Budak, S., Z. Xiao, B. Johnson, J. Cole and M. Drabo et al., 2016. Highly-efficient advanced thermoelectric devices from different multilayer thin films. Am. J. Eng. Applied Sci., 9: 356-363.

DOI: 10.3844/ajeassp.2016.356.363

Buonomano, A., F. Calise and M. Vicidomini, 2016a. A novel prototype of a small-scale solar power plant: Dynamic simulation and thermoeconomic analysis. Am. J. Eng. Applied Sci., 9: 770-788.

DOI: 10.3844/ajeassp.2016.770.788

Buonomano, A., F. Calise, M.D. d'Accadia, R. Vanoli and M. Vicidomini, 2016b. Simulation and experimental analysis of a demonstrative solar heating and cooling plant installed in Naples (Italy). Am. J. Eng. Applied Sci., 9: 798-813. DOI: 10.3844/ajeassp.2016.798.813 
Calise, F., M.D. dâ' Accadia, L. Libertini, E. Quiriti and M. Vicidomini, 2016. Dynamic simulation and optimum operation strategy of a trigeneration system serving a hospital. Am. J. Eng. Applied Sci., 9: 854-867. DOI: 10.3844/ajeassp.2016.854.867

Campo, T., M. Cotto, F. Marquez, E. Elizalde and C. Morant, 2016. Graphene synthesis by plasmaenhanced CVD growth with ethanol. Am. J. Eng. Applied Sci., 9: 574-583.

DOI: 10.3844/ajeassp.2016.574.583

Cardu, M., P. Oreste and T. Cicala, 2009. Analysis of the tunnel boring machine advancement on the bolognaflorence railway link. Am. J. Eng. Applied Sci., 2: 416-420. DOI: 10.3844/ajeassp.2009.416.420

Chen, G. and L. Xu, 2016. A general strategy to enhance upconversion luminescence in rare-earth-ion-doped oxide nanocrystals. Am. J. Eng. Applied Sci., 9: 79-83. DOI: 10.3844/ajeassp.2016.79.83

Chiozzi, A., G. Milani, N. Grillanda and A. Tralli, 2016. An adaptive procedure for the limit analysis of FRP reinforced masonry vaults and applications. Am. J. Eng. Applied Sci., 9: 735-745.

DOI: 10.3844/ajeassp.2016.735.745

Chisari, C. and C. Bedon, 2016. Multi-objective optimization of FRP jackets for improving the seismic response of reinforced concrete frames. Am. J. Eng. Applied Sci., 9: 669-679.

DOI: 10.3844/ajeassp.2016.669.679

Darabi, A., S.A. Soleamani and A. Hassannia, 2008. Fuzzy based digital automatic voltage regulator of a synchronous generator with unbalanced loads. Am. J. Eng. Applied Sci., 1: 280-286. DOI: 10.3844/ajeassp.2008.280.286

Daud, H., N. Yahya, A.A. Aziz and M.F. Jusoh, 2008. Development of wireless electric concept powering electrical appliances. Am. J. Eng. Applied Sci., 1: 12-15. DOI: 10.3844/ajeassp.2008.12.15

Djalel, D., M. Mourad and H. Labar, 2013. New approach of electromagnetic fields of the lightning discharge. Am. J. Eng. Applied Sci., 6: 369-383. DOI: 10.3844/ajeassp.2013.369.383

dos Santos, F.A. and C. Bedon, 2016. Preliminary experimental and finite-element numerical assessment of the structural performance of SMAreinforced GFRP systems. Am. J. Eng. Applied Sci., 9: 692-701. DOI: 10.3844/ajeassp.2016.692.701

Ebrahim, N.A., S. Ahmed, S.H.A. Rashid and Z. Taha, 2012. Technology use in the virtual R\&D teams. Am. J. Eng. Applied Sci., 5: 9-14.

DOI: 10.3844/ajeassp.2012.9.14

El-Labban, H.F., M. Abdelaziz and E.R.I. Mahmoud, 2013. Modification of carbon steel by laser surface melting: Part I: Effect of laser beam travelling speed on microstructural features and surface hardness. Am. J. Eng. Applied Sci., 6: 352-359.

DOI: 10.3844/ajeassp.2013.352.359
Elliott, A., S. AlSalihi, A.L. Merriman and M.M. Basti, 2016. Infiltration of nanoparticles into porous binder jet printed parts. Am. J. Eng. Applied Sci., 9: 128-133. DOI: 10.3844/ajeassp.2016.128.133

Elmeddahi, Y., H. Mahmoudi, A. Issaadi, M.F.A. Goosen and R. Ragab, 2016b. Evaluating the effects of climate change and variability on water resources: A case study of the cheliff basin in Algeria. Am. J. Eng. Applied Sci., 9: 835-845. DOI: 10.3844/ajeassp.2016.835.845

El-Tous, Y., 2008. Pitch angle control of variable speed wind turbine. Am. J. Eng. Applied Sci., 1: 118-120. DOI: 10.3844/ajeassp.2008.118.120

Faizal, A., S. Mulyono, R. Yendra and A. Fudholi, 2016. Design Maximum Power Point Tracking (MPPT) on photovoltaic panels using fuzzy logic method. Am. J. Eng. Applied Sci., 9: 789-797.

DOI: $10.3844 /$ ajeassp.2016.789.797

Farahani, A.S., N.M. Adam and M.K.A. Ariffin, 2010. Simulation of airflow and aerodynamic forces acting on a rotating turbine ventilator. Am. J. Eng. Applied Sci., 3: 159-170. DOI: 10.3844/ajeassp.2010.159.170

Fathallah, A.Z.M. and R.A. Bakar, 2009. Prediction studies for the performance of a single cylinder high speed spark ignition linier engine with spring mechanism as return cycle. Am. J. Eng. Applied Sci., 2: 713-720. DOI: 10.3844/ajeassp.2009.713.720

Fen, Y.W., W.M.M. Yunus, M.M. Moksin, Z.A. Talib and N.A. Yusof, 2011. Optical properties of crosslinked chitosan thin film with glutaraldehyde using surface Plasmon resonance technique. Am. J. Eng. Applied Sci., 4: 61-65. DOI: 10.3844/ajeassp.2011.61.65

Feraga, C.E., A. Moussaoui, A. Bouldjedri and A. Yousfi, 2009. Robust position controller for a permanent magnet synchronous actuator. Am. J. Eng. Applied Sci., 2: 388-392.

DOI: 10.3844/ajeassp.2009.388.392

Gusti, A.P. and Semin, 2016. The effect of vessel speed on fuel consumption and exhaust gas emissions. Am. J. Eng. Applied Sci., 9: 1046-1053. DOI: 10.3844 /ajeassp.2016.1046.1053

Hassan, M., H. Mahjoub and M. Obed, 2012. Voicebased control of a DC servo motor. Am. J. Eng. Applied Sci., 5: 89-92.

DOI: 10.3844/ajeassp.2012.89.92

Hasan, S. and M.H. El-Naas, 2016. Optimization of a combined approach for the treatment of carbide slurry and capture of $\mathrm{CO}_{2}$. Am. J. Eng. Applied Sci., 9: 449-457. DOI: 10.3844/ajeassp.2016.449.457

Helmy, A.K. and G.S. El-Taweel, 2010. Neural network change detection model for satellite images using textural and spectral characteristics. Am. J. Eng. Applied Sci., 3: 604-610.

DOI: 10.3844/ajeassp.2010.604.610 
Hirun, W., 2016. Evaluation of interregional freight generation modelling methods by using nationwide commodity flow survey data. Am. J. Eng. Applied Sci., 9: 625-634.

DOI: 10.3844/ajeassp.2016.625.634

Ho, C.Y.F., B.W.K. Ling, S.G. Blasi, Z.W. Chi and W.C. Siu, 2011. Single step optimal block matched motion estimation with motion vectors having arbitrary pixel precisions. Am. J. Eng. Applied Sci., 4: 448-460. DOI: 10.3844/ajeassp.2011.448.460

Huang, B., S.H. Masood, M. Nikzad, P.R. Venugopal and A. Arivazhagan, 2016. Dynamic mechanical properties of fused deposition modelling processed polyphenylsulfone material. Am. J. Eng. Applied Sci., 9: 1-11. DOI: 10.3844/ajeassp.2016.1.11

Idarwazeh, S., 2011. Inverse discrete Fourier transformdiscrete Fourier transform techniques for generating and receiving spectrally efficient frequency division multiplexing signals. Am. J. Eng. Applied Sci., 4: 598-606. DOI: 10.3844/ajeassp.2011.598.606

Iqbal, M., 2016. An overview of Energy Loss Reduction (ELR) software used in Pakistan by WAPDA for calculating transformer overloading, line losses and energy losses. Am. J. Eng. Applied Sci., 9: 442-448. DOI: 10.3844/ajeassp.2016.442.448

Ismail, M.I.S., Y. Okamoto, A. Okada and Y. Uno, 2011. Experimental investigation on micro-welding of thin stainless steel sheet by fiber laser. Am. J. Eng. Applied Sci., 4: 314-320.

DOI: 10.3844/ajeassp.2011.314.320

Jaber, A.A. and R. Bicker, 2016. Industrial robot fault detection based on statistical control chart. Am. J. Eng. Applied Sci., 9: 251-263.

DOI: 10.3844/ajeassp.2016.251.263

Jafari, N., A. Alsadoon, C.P. Withana, A. Beg and A. Elchouemi, 2016. Designing a comprehensive security framework for smartphones and mobile devices. Am. J. Eng. Applied Sci., 9: 724-734.

DOI: 10.3844/ajeassp.2016.724.734

Jalil, M.I.A. and J. Sampe, 2013. Experimental investigation of thermoelectric generator modules with different technique of cooling system. Am. J. Eng. Applied Sci., 6: 1-7.

DOI: 10.3844/ajeassp.2013.1.7

Jaoude, A.A. and K. El-Tawil, 2013. Analytic and nonlinear prognostic for vehicle suspension systems. Am. J. Eng. Applied Sci., 6: 42-56.

DOI: 10.3844 /ajeassp.2013.42.56

Jarahi, H., 2016. Probabilistic seismic hazard deaggregation for Karaj City (Iran). Am. J. Eng. Applied Sci., 9: 520-529.

DOI: 10.3844/ajeassp.2016.520.529

Jarahi, H. and S. Seifilaleh, 2016. Rock fall hazard Zonation in Haraz highway. Am. J. Eng. Applied Sci., 9: 371-379.

DOI: 10.3844/ajeassp.2016.371.379
Jauhari, K., A. Widodo and I. Haryanto, 2016. Identification of a machine tool spindle critical frequency through modal and imbalance response analysis. Am. J. Eng. Applied Sci., 9: 213-221.

DOI: 10.3844/ajeassp.2016.213.221

Jiang, J., Q. Chen and S. Nimbalkar, 2016. Field data based method for predicting long-term settlements. Am. J. Eng. Applied Sci., 9: 466-476.

DOI: $10.3844 /$ ajeassp.2016.466.476

Kaewnai, S. and S. Wongwises, 2011. Improvement of the runner design of Francis turbine using computational fluid dynamics. Am. J. Eng. Applied Sci., 4: 540-547. DOI: 10.3844/ajeassp.2011.540.547

Kamble, V.G. and N. Kumar, 2016. Fabrication and tensile property analysis of polymer matrix composites of graphite and silicon carbide as fillers. Am. J. Eng. Applied Sci., 9: 17-30.

DOI: 10.3844/ajeassp.2016.17.30

Kazakov, V.V., V.I. Yusupov, V.N. Bagratashvili, A.I. Pavlikov and V.A. Kamensky, 2016. Control of bubble formation at the optical fiber tip by analyzing ultrasound acoustic waves. Am. J. Eng. Applied Sci., 9: 921-927.

DOI: 10.3844/ajeassp.2016.921.927

Kechiche, O.B.H.B., H.B.A. Sethom, H. Sammoud and I.S. Belkhodja, 2011. Optimized high-frequency signal injection based permanent magnet synchronous motor rotor position estimation applied to washing machines. Am. J. Eng. Applied Sci., 4: 390-399. DOI: 10.3844/ajeassp.2011.390.399

Kuli, I., T.M. Abu-Lebdeh, E.H. Fini and S.A. Hamoush, 2016. The use of nano-silica for improving mechanical properties of hardened cement paste. Am. J. Eng. Applied Sci., 9: 146-154. DOI: 10.3844/ajeassp.2016.146.154

Kunanoppadon, J., 2010. Thermal efficiency of a combined turbocharger set with gasoline engine. Am. J. Eng. Applied Sci., 3: 342-349.

DOI: 10.3844/ajeassp.2010.342.349

Kwon, S., Y. Tani, H. Okubo and T. Shimomura, 2010. Fixed-star tracking attitude control of spacecraft using single-gimbal control moment gyros. Am. J. Eng. Applied Sci., 3: 49-55.

DOI: 10.3844/ajeassp.2010.49.55

Lamarre, A., E.H. Fini and T.M. Abu-Lebdeh, 2016. Investigating effects of water conditioning on the adhesion properties of crack sealant. Am. J. Eng. Applied Sci., 9: 178-186.

DOI: 10.3844/ajeassp.2016.178.186

Lubis, Z., A.N. Abdalla, Mortaza and R. Ghon, 2009. Mathematical modeling of the three phase induction motor couple to DC motor in hybrid electric vehicle. Am. J. Eng. Applied Sci., 2: 708-712. DOI: 10.3844 /ajeassp.2009.708.712 
Madani, D.A.L. and A. Dababneh, 2016. Rapid entire body assessment: A literature review. Am. J. Eng. Applied Sci., 9: 107-118. DOI: 10.3844/ajeassp.2016.107.118

Malomar, G.E.B., A. Gueye, C. Mbow, V.B. Traore and A.C. Beye, 2016. Numerical study of natural convection in a square porous cavity thermally modulated on both side walls. Am. J. Eng. Applied Sci., 9: 591-598. DOI: 10.3844/ajeassp.2016.591.598

Mansour, M.A.A., 2016. Developing an anthropometric database for Saudi students and comparing Saudi dimensions relative to Turkish and Iranian peoples. Am. J. Eng. Applied Sci., 9: 547-557.

DOI: 10.3844/ajeassp.2016.547.557

Marghany, M. and M. Hashim, 2009. Robust of doppler centroid for mapping sea surface current by using radar satellite data. Am. J. Eng. Applied Sci., 2: 781-788. DOI: 10.3844/ajeassp.2009.781.788

Martins, F.R., A.R. Gonçalves and E.B. Pereira, 2016. Observational study of wind shear in Northeastern Brazil. Am. J. Eng. Applied Sci., 9: 484-504. DOI: 10.3844/ajeassp.2016.484.504

Mavukkandy, M.O., S. Chakraborty, T. Abbasi and S.A. Abbasi, 2016. A clean-green synthesis of platinum nanoparticles utilizing a pernicious weed lantana (Lantana Camara). Am. J. Eng. Applied Sci., 9: 84-90. DOI: 10.3844/ajeassp.2016.84.90

Minghini, F., N. Tullini and F. Ascione, 2016. Updating Italian design guide CNR DT-205/2007 in view of recent research findings: Requirements for pultruded FRP profiles. Am. J. Eng. Applied Sci., 9: 702-712. DOI: 10.3844/ajeassp.2016.702.712

Moezi, N., D. Dideban and A. Ketabi, 2008. A novel integrated SET based inverter for Nano power electronic applications. Am. J. Eng. Applied Sci., 1: 219-222. DOI: 10.3844/ajeassp.2008.219.222

Mohamed, M.A., A.Y. Tuama, M. Makhtar, M.K. Awang and M. Mamat, 2016. The effect of RSA exponential key growth on the multi-core computational resource. Am. J. Eng. Applied Sci., 9: 1054-1061. DOI: 10.3844/ajeassp.2016.1054.1061

Mohan, K.S.R., P. Jayabalan and A. Rajaraman, 2012. Properties of fly ash based coconut fiber composite. Am. J. Eng. Applied Sci., 5: 29-34.

DOI: 10.3844 /ajeassp.2012.29.34

Mohseni, E. and K.D. Tsavdaridis, 2016. Effect of nanoalumina on pore structure and durability of class $\mathrm{F}$ fly ash self-compacting mortar. Am. J. Eng. Applied Sci., 9: 323-333.

DOI: 10.3844/ajeassp.2016.323.333

Momani, M.A., T.A. Al Smadi, FM. Al Taweel and K.A. Ghaidan, 2011. GPS ionospheric total electron content and scintillation measurements during the October 2003 magnetic storm. Am. J. Eng. Applied Sci., 4: 301-306.

DOI: 10.3844/ajeassp.2011.301.306
Mondal, R., S. Sahoo and C.S. Rout, 2016. Mixed nickel cobalt manganese oxide nanorods for supercapacitor application. Am. J. Eng. Applied Sci., 9: 540-546. DOI: 10.3844/ajeassp.2016.540.546

Montgomery, J., T.M. Abu-Lebdeh, S.A. Hamoush and M. Picornell, 2016. Effect of nano-silica on the compressive strength of harden cement paste at different stages of hydration. Am. J. Eng. Applied Sci., 9: 166-177.

DOI: $10.3844 /$ ajeassp.2016.166.177

Morse, A., M.M. Mansfield, R.M. Alley, H.A. Kerr and R.B. Bucinell, 2016b. Traction enhancing products affect maximum torque at the shoe-floor interface: A potential increased risk of ACL injury. Am. J. Eng. Applied Sci., 9: 889-893.

DOI: 10.3844/ajeassp.2016.889.893

Moubarek, T. and A. Gharsallah, 2016. A six-port reflectometer calibration using Wilkinson power divider. Am. J. Eng. Applied Sci., 9: 274-280. DOI: 10.3844/ajeassp.2016.274.280

Nabilou, A., 2016a. Effect of parameters of selection and replacement drilling bits based on geo-mechanical factors: (case study: Gas and oil reservoir in the Southwest of Iran). Am. J. Eng. Applied Sci., 9: 380-395. DOI: 10.3844/ajeassp.2016.380.395

Nabilou, A., 2016b. Study of the parameters of Steam Assisted Gravity Drainage (SAGD) method for enhanced oil recovery in a heavy oil fractured carbonate reservoir. Am. J. Eng. Applied Sci., 9: 647-658. DOI: 10.3844/ajeassp.2016.647.658

Nachiengtai, T., W. Chim-Oye, S. Teachavorasinskun and W. Sa-Ngiamvibool, 2008. Identification of shear band using elastic shear wave propagation. Am. J. Eng. Applied Sci., 1: 188-191.

DOI: 10.3844/ajeassp.2008.188.191

Nahas, R. and S.P. Kozaitis, 2014. Metric for the fusion of synthetic and real imagery from multimodal sensors. Am. J. Eng. Applied Sci., 7: 355-362. DOI: 10.3844/ajeassp.2014.355.362

Nandhakumar, S., V. Selladurai and S. Sekar, 2009. Numerical investigation of an industrial robot arm control problem using haar wavelet series. Am. J. Eng. Applied Sci., 2: 584-589.

DOI: $10.3844 /$ ajeassp.2009.584.589

Obaiys, S.J., Z. Abbas, N.M.A. Nik Long, A.F. Ahmad and A. Ahmedov et al., 2016. On the general solution of first-kind hypersingular integral equations. Am. J. Eng. Applied Sci., 9: 195-201. DOI: 10.3844/ajeassp.2016.195.201

Odeh, S., R. Faqeh, L. Abu Eid and N. Shamasneh, 2009. Vision-based obstacle avoidance of mobile robot using quantized spatial model. Am. J. Eng. Applied Sci., 2: 611-619.

DOI: 10.3844/ajeassp.2009.611.619 
Opafunso, Z.O., I.I. Ozigis and I.A. Adetunde, 2009. Pneumatic and hydraulic systems in coal fluidized bed combustor. Am. J. Eng. Applied Sci., 2: 88-95. DOI: 10.3844 /ajeassp.2009.88.95

Orlando, N. and E. Benvenuti, 2016. Advanced XFEM simulation of pull-out and debonding of steel bars and FRP-reinforcements in concrete beams. Am. J. Eng. Applied Sci., 9: 746-754.

DOI: 10.3844/ajeassp.2016.746.754

Pannirselvam, N., P.N. Raghunath and K. Suguna, 2008. Neural network for performance of glass fibre reinforced polymer plated RC beams. Am. J. Eng. Applied Sci., 1: 82-88.

DOI: 10.3844 /ajeassp.2008.82.88

Pattanasethanon, S., 2010. The solar tracking system by using digital solar position sensor. Am. J. Eng. Applied Sci., 3: 678-682.

DOI: 10.3844/ajeassp.2010.678.682

Pérez-de León, G., V.E. Lamberti, R.D. Seals, T.M. Abu-Lebdeh and S.A. Hamoush 2016. Gas atomization of molten metal: Part I. Numerical modeling conception. Am. J. Eng. Applied Sci., 9: 303-322. DOI: 10.3844/ajeassp.2016.303.322

Petrescu, R.V. and F.I. Petrescu, 2013a. Lockheed Martin. 1st Edn., BoD-Books on Demand, ISBN-10: 3848230739, pp: 114.

Petrescu, R.V. and F.I. Petrescu, 2013b. Northrop. 1st Edn., CreateSpace, pp: 96.

Petrescu, R.V. and F.I. Petrescu, 2013c. The Aviation History or New Aircraft I Color. 1st Edn., CreateSpace, pp: 292.

Petrescu, F.I. and R.V. Petrescu, 2012. New Aircraft II. 1st Edn., Books On Demand, pp: 138.

Petrescu, F.I. and R.V. Petrescu, 2011. Memories about Flight. 1st Edn., CreateSpace, pp: 652.

Petrescu, F.I.T., 2018. About the nuclear particles' structure and dimensions. Comp. Part. Mech. DOI: $10.1007 / \mathrm{s} 40571-018-0206-7$

Petrescu, F.I.T., 2015a. Geometrical synthesis of the distribution mechanisms. Am. J. Eng. Applied Sci., 8: 63-81. DOI: 10.3844/ajeassp.2015.63.81

Petrescu, F.I.T., 2015b. Machine motion equations at the internal combustion heat engines. Am. J. Eng. Applied Sci., 8: 127-137.

DOI: 10.3844/ajeassp.2015.127.137

Petrescu, R.V., R. Aversa, A. Apicella, S. Li and G. Chen et al., 2016a. Something about electron dimension. Am. J. Applied Sci., 13: 1272-1276. DOI: 10.3844/ajassp.2016.1272.1276

Petrescu, F.I.T., A. Apicella, R. Aversa, R.V. Petrescu and J.K. Calautit et al., 2016b. Something about the mechanical moment of inertia. Am. J. Applied Sci., 13: 1085-1090.

DOI: 10.3844 /ajassp.2016.1085.1090
Petrescu, F.I.T., A. Apicella, R.V. Petrescu, S.P. Kozaitis and R.B. Bucinell et al., 2016c. Environmental protection through nuclear energy. Am. J. Applied Sci., 13: 941-946.

DOI: 10.3844/ajassp.2016.941.946

Petrescu, R.V., R. Aversa, B. Akash, F. Berto and A. Apicella et al., 2017a. Forces of a 3R robot. J. Mechatron. Robot., 1: 1-14. DOI: $10.3844 /$ jmrsp.2017.1.14

Petrescu, R.V., R. Aversa, B. Akash, F. Berto and A. Apicella et al., 2017b. Direct geometry and cinematic to the MP-3R systems. J. Mechatron. Robot., 1: 15-23. DOI: 10.3844/jmrsp.2017.15.23

Petrescu, R.V., R. Aversa, B. Akash, F. Berto and A. Apicella et al., 2017c. Dynamic elements at MP3R. J. Mechatron. Robot., 1: 24-37. DOI: 10.3844/jmrsp.2017.24.37

Petrescu, R.V., R. Aversa, B. Akash, F. Berto and A. Apicella et al., 2017d. Geometry and direct kinematics to MP3R with $4 \times 4$ operators. J. Mechatron. Robot., 1: 38-46. DOI: 10.3844/jmrsp.2017.38.46

Petrescu, R.V., R. Aversa, A. Apicella, M.M. Mirsayar and S. Kozaitis et al., 2017e. Current stage in the field of mechanisms with gears and rods. J. Mechatron. Robot., 1: 47-57.

DOI: $10.3844 /$ jmrsp.2017.47.57

Petrescu, R.V., R. Aversa, A. Apicella, M.M. Mirsayar and S. Kozaitis et al., 2017f. Geometry and inverse kinematic at the MP3R mobile systems. J. Mechatron. Robot., 1: 58-65. DOI: $10.3844 /$ jmrsp.2017.58.65

Petrescu, R.V., R. Aversa, A. Apicella, M.M. Mirsayar and S. Kozaitis et al., 2017g. Synthesis of optimal trajectories with functions control at the level of the kinematic drive couplings. J. Mechatron. Robot., 1: 66-74. DOI: 10.3844/jmrsp.2017.66.74

Petrescu, R.V., R. Aversa, A. Apicella, M.M. Mirsayar and S. Kozaitis et al., 2017h. The inverse kinematics of the plane system 2-3 in a mechatronic MP2R system, by a trigonometric method. J. Mechatron. Robot., 1: 75-87. DOI: 10.3844/jmrsp.2017.75.87

Petrescu, R.V., R. Aversa, A. Apicella, M.M. Mirsayar and S. Kozaitis et al., 2017i. Serial, anthropomorphic, spatial, mechatronic systems can be studied more simply in a plan. J. Mechatron. Robot., 1: 88-97. DOI: 10.3844/jmrsp.2017.88.97

Petrescu, R.V., R. Aversa, A. Apicella, M.M. Mirsayar and S. Kozaitis et al., 2017j. Analysis and synthesis of mechanisms with bars and gears used in robots and manipulators. J. Mechatron. Robot., 1: 98-108. DOI: $10.3844 /$ jmrsp.2017.98.108

Petrescu, R.V., R. Aversa, A. Apicella, M.M. Mirsayar and S. Kozaitis et al., 2017k. Speeds and accelerations in direct kinematics to the MP3R systems. J. Mechatron. Robot., 1: 109-117. DOI: 10.3844/jmrsp.2017.109.117 
Petrescu, R.V., R. Aversa, A. Apicella, M.M. Mirsayar and S. Kozaitis et al., 20171. Geometry and determining the positions of a plan transporter manipulator. J. Mechatron. Robot., 1: 118-126. DOI: $10.3844 /$ jmrsp.2017.118.126

Petrescu, R.V., R. Aversa, A. Apicella and F.I.T. Petrescu, 2018a. Total Static Balancing and Kinetostatics of the 3R Base Cinematic Chain. J. Mechatron. Robot., 2: 1-13. DOI: 10.3844/jmrsp.2018.1.13

Petrescu, R.V., R. Aversa, A. Apicella and F.I.T. Petrescu, 2018b. Switching from Flat to Spatial Motion to 3R Mechatronic Systems. J. Mechatron. Robot., 2: 14-22. DOI: 10.3844/jmrsp.2018.14.22

Petrescu, R.V., R. Aversa, A. Apicella and F.I.T. Petrescu, 2018c. The dynamics of the planar cinematic balanced chain at the plan module 3R. J. Mechatron. Robot., 2: 23-34. DOI: 10.3844/jmrsp.2018.23.34

Petrescu, R.V., R. Aversa, A. Apicella and F.I.T. Petrescu, 2018d. Dynamic Kinematics of the Plan Balanced Chain at the Planar Module 3R. J. Mechatron. Robot., 2: 35-44.

DOI: $10.3844 /$ jmrsp.2018.35.44

Petrescu, F.I.T. and J.K. Calautit, 2016a. About nano fusion and dynamic fusion. Am. J. Applied Sci., 13: 261-266. DOI: 10.3844/ajassp.2016.261.266

Petrescu, F.I.T. and J.K. Calautit, 2016b. About the light dimensions. Am. J. Applied Sci., 13: 321-325. DOI: 10.3844/ajassp.2016.321.325

Petrescu, F.I.T., 2012a. Cold nuclear fusion. Plasma Phys. Fusion Technol., 44: 100-100.

Petrescu, F.I.T., 2012b. China. 1st Edn., CreateSpace Independent Publisher, ISBN-13: 978-1469973623, pp: 232.

Pisello, A.L., G. Pignatta, C. Piselli, V.L. Castaldo and F. Cotana, 2016. Investigating the dynamic thermal behavior of building envelope in summer conditions by means of in-field continuous monitoring. Am. J. Eng. Applied Sci., 9: 505-519.

DOI: 10.3844/ajeassp.2016.505.519

Pourmahmoud, N., 2008. Rarefied gas flow modeling inside rotating circular cylinder. Am. J. Eng. Applied Sci., 1: 62-65.

DOI: 10.3844/ajeassp.2008.62.65

Pravettoni, M., C.S.P. Lòpez and R.P. Kenny, 2016. Impact of the edges of a backside diffusive reflector on the external quantum efficiency of luminescent solar concentrators: experimental and computational approach. Am. J. Eng. Applied Sci., 9: 53-63.

DOI: 10.3844 /ajeassp.2016.53.63

Qutbodin, K., 2010. Merging autopilot/flight control and navigation-flight management systems. Am. J. Eng. Applied Sci., 3: 629-630.

DOI: 10.3844/ajeassp.2010.629.630
Rajbhandari, S., Z. Ghassemlooy and M. Angelova, 2011. The performance of a dual header pulse interval modulation in the presence of artificial light interferences in an indoor optical wireless communications channel with wavelet denoising. Am. J. Eng. Applied Sci., 4: 513-519.

DOI: 10.3844/ajeassp.2011.513.519

Rajput, R.S., S. Pandey and S. Bhadauria, 2016. Correlation of biodiversity of algal genera with special reference to the waste water effluents from industries. Am. J. Eng. Applied Sci., 9: 1127-1133. DOI: 10.3844/ajeassp.2016.1127.1133

Raptis, K.G., G.A. Papadopoulos, T.N. Costopoulos and A.D. Tsolakis, 2011. Experimental study of load sharing in roller-bearing contact by caustics and photoelasticity. Am. J. Eng. Applied Sci., 4: 294-300. DOI: 10.3844/ajeassp.2011.294.300

Rama, G., D. Marinkovic and M. Zehn, 2016. Efficient co-rotational 3-node shell element. Am. J. Eng. Applied Sci., 9: 420-431.

DOI: 10.3844/ajeassp.2016.420.431

Rea, P. and E. Ottaviano, 2016. Analysis and mechanical design solutions for sit-to-stand assisting devices. Am. J. Eng. Applied Sci., 9: 1134-1143. DOI: 10.3844/ajeassp.2016.1134.1143

Riccio, A., U. Caruso, A. Raimondo and A. Sellitto, 2016a. Robustness of XFEM method for the simulation of cracks propagation in fracture mechanics problems. Am. J. Eng. Applied Sci., 9: 599-610. DOI: 10.3844/ajeassp.2016.599.610

Riccio, A., R. Cristiano and S. Saputo, 2016b. A brief introduction to the bird strike numerical simulation. Am. J. Eng. Applied Sci., 9: 946-950.

DOI: 10.3844/ajeassp.2016.946.950

Rich, F. and M.A. Badar, 2016. Statistical analysis of auto dilution $\mathrm{Vs}$ manual dilution process in inductively coupled plasma spectrometer tests. Am. J. Eng. Applied Sci., 9: 611-624.

DOI: 10.3844/ajeassp.2016.611.624

Rohit, K. and S. Dixit, 2016. Mechanical properties of waste Biaxially Oriented Polypropylene Metallized Films (BOPP), LLDPE: LDPE Films with Sisal Fibres. Am. J. Eng. Applied Sci., 9: 913-920. DOI: 10.3844/ajeassp.2016.913.920

Rulkov, N.F., A.M. Hunt, P.N. Rulkov and A.G. Maksimov, 2016. Quantization of map-based neuronal model for embedded simulations of neurobiological networks in real-time. Am. J. Eng. Applied Sci., 9: 973-984. DOI: 10.3844/ajeassp.2016.973.984

Saikia, A. and N. Karak, 2016. Castor oil based epoxy/clay nanocomposite for advanced applications. Am. J. Eng. Applied Sci., 9: 31-40. DOI: 10.3844/ajeassp.2016.31.40 
Sallami, A., N. Zanzouri and M. Ksouri, 2016. Robust diagnosis of a DC motor by bond graph approach. Am. J. Eng. Applied Sci., 9: 432-438.

DOI: 10.3844/ajeassp.2016.432.438

Samantaray, K.S., S. Sahoo and C.S. Rout, 2016. Hydrothermal synthesis of $\mathrm{CuWO}_{4}$-reduced graphene oxide hybrids and supercapacitor application. Am. J. Eng. Applied Sci., 9: 584-590. DOI: 10.3844/ajeassp.2016.584.590

Semin, A.R. Ismail and R.A. Bakar, 2009a. Combustion temperature effect of diesel engine convert to compressed natural gas engine. Am. J. Eng. Applied Sci., 2: 212-216.

DOI: 10.3844/ajeassp.2009.212.216

Semin, A.R. Ismail and R.A. Bakar, 2009b. Effect of diesel engine converted to sequential port injection compressed natural gas engine on the cylinder pressure Vs crank angle in variation engine speeds. Am. J. Eng. Applied Sci., 2: 154-159. DOI: 10.3844/ajeassp.2009.154.159

Semin S., A.R. Ismail and R.A. Bakar, 2009c. Diesel engine convert to port injection $\mathrm{CNG}$ engine using gaseous injector nozzle multi holes geometries improvement: A review. Am. J. Eng. Applied Sci., 2: 268-278.

DOI: 10.3844/ajeassp.2009.268.278

Semin and R.A. Bakar, 2008. A technical review of compressed natural gas as an alternative fuel for internal combustion engines. Am. J. Eng. Applied Sci., 1: 302-311.

DOI: 10.3844/ajeassp.2008.302.311

Sepúlveda, J.A.M., 2016. Outlook of municipal solid waste in Bogota (Colombia). Am. J. Eng. Applied Sci., 9: 477-483.

DOI: 10.3844/ajeassp.2016.477.483

Serebrennikov, A., D. Serebrennikov and Z. Hakimov, 2016. Polyethylene pipeline bending stresses at an installation. Am. J. Eng. Applied Sci., 9: 350-355. DOI: 10.3844/ajeassp.2016.350.355

Shanmugam, K., 2016. Flow dynamic behavior of fish oil/silver nitrate solution in mini-channel, effect of alkane addition on flow pattern and interfacial tension. Am. J. Eng. Applied Sci., 9: 236-250. DOI: 10.3844/ajeassp.2016.236.250

Shruti, 2016. Comparison in cover media under stegnography: Digital media by hide and seek approach. Am. J. Eng. Applied Sci., 9: 297-302. DOI: 10.3844/ajeassp.2016.297.302

Suarez, L., T.M. Abu-Lebdeh, M. Picornell and S.A. Hamoush, 2016. Investigating the role of fly ash and silica fume in the cement hydration process. Am. J. Eng. Applied Sci., 9: 134-145.

DOI: 10.3844/ajeassp.2016.134.145
Syahrullah, O.I. and N. Sinaga, 2016. Optimization and prediction of motorcycle injection system performance with feed-forward back-propagation method Artificial Neural Network (ANN). Am. J. Eng. Applied Sci., 9: 222-235.

DOI: 10.3844/ajeassp.2016.222.235

Taher, S.A., R. Hematti and M. Nemati, 2008. Comparison of different control strategies in GAbased optimized UPFC controller in electric power systems. Am. J. Eng. Applied Sci., 1: 45-52. DOI: 10.3844/ajeassp.2008.45.52

Theansuwan, W. and K. Triratanasirichai, 2011. The biodiesel production from roast Thai sausage oil by transesterification reaction. Am. J. Eng. Applied Sci., 4: 130-132.

DOI: 10.3844/ajeassp.2011.130.132

Thongwan, T., A. Kangrang and S. Homwuttiwong, 2011. An estimation of rainfall using fuzzy setgenetic algorithms model. Am. J. Eng. Applied Sci., 4: 77-81.

DOI: 10.3844/ajeassp.2011.77.81

Tourab, W., A. Babouri and M. Nemamcha, 2011. Experimental study of electromagnetic environment in the vicinity of high voltage lines. Am. J. Eng. Applied Sci., 4: 209-213.

DOI: 10.3844/ajeassp.2011.209.213

Tsolakis, A.D. and K.G. Raptis, 2011. Comparison of maximum gear-tooth operating bending stresses derived from niemann's analytical procedure and the finite element method. Am. J. Eng. Applied Sci., 4: 350-354.

DOI: 10.3844/ajeassp.2011.350.354

Wang, L., T. Liu, Y. Zhang and X. Yuan, 2016. A methodology for continuous evaluation of cloud resiliency. Am. J. Eng. Applied Sci., 9: 264-273. DOI: 10.3844/ajeassp.2016.264.273

Wang, J. and Y. Yagi, 2016. Fragment-based visual tracking with multiple representations. Am. J. Eng. Applied Sci., 9: 187-194. DOI: 10.3844/ajeassp.2016.187.194

Waters, C., S. Ajinola and M. Salih, 2016. Dissolution sintering technique to create porous copper with sodium chloride using polyvinyl alcohol solution through powder metallurgy. Am. J. Eng. Applied Sci., 9: 155-165.

DOI: 10.3844/ajeassp.2016.155.165

Wessels, L. and H. Raad, 2016. Recent advances in point of care diagnostic tools: A review. Am. J. Eng. Applied Sci., 9: 1088-1095.

DOI: 10.3844/ajeassp.2016.1088.1095

Yeargin, R., R. Ramey and C. Waters, 2016. Porosity analysis in porous brass using dual approaches. Am. J. Eng. Applied Sci., 9: 91-97. DOI: 10.3844/ajeassp.2016.91.97 
You, M., X. Huang, M. Lin, Q. Tong and X. Li et al., 2016. Preparation of $\mathrm{LiCoMnO}_{4}$ assisted by hydrothermal approach and its electrochemical performance. Am. J. Eng. Applied Sci., 9: 396-405. DOI: 10.3844/ajeassp.2016.396.405

Zeferino, R.S., J.A.R. Ramón, E. de Anda Reyes, R.S. González and U. Pal, 2016. Large scale synthesis of $\mathrm{ZnO}$ nanostructures of different morphologies through solvent-free mechanochemical synthesis and their application in photocatalytic dye degradation. Am. J. Eng. Applied Sci., 9: 41-52. DOI: 10.3844/ajeassp.2016.41.52

Zhao, B., 2013. Identification of multi-cracks in the gate rotor shaft based on the wavelet finite element method. Am. J. Eng. Applied Sci., 6: 309-319.

DOI: 10.3844/ajeassp.2013.309.319

Zheng, $\mathrm{H}$. and $\mathrm{S}$. Li, 2016. Fast and robust maximum power point tracking for solar photovoltaic systems. Am. J. Eng. Applied Sci., 9: 755-769.

DOI: 10.3844/ajeassp.2016.755.769

Zotos, I.S. and T.N. Costopoulos, 2009. On the use of rolling element bearings' models in precision maintenance. Am. J. Eng. Applied Sci., 2: 344-352. DOI: 10.3844/ajeassp.2009.344.352
Zulkifli, R., K. Sopian, S. Abdullah and M.S. Takriff, 2008. Effect of pulsating circular hot air jet frequencies on local and average nusselt number. Am. J. Eng. Applied Sci., 1: 57-61. DOI: $10.3844 /$ ajeassp.2008.57.61

Zulkifli, R., K. Sopian, S. Abdullah and M.S. Takriff, 2009. Experimental study of flow structures of circular pulsating air jet. Am. J. Eng. Applied Sci., 2: 171-175. DOI: 10.3844/ajeassp.2009.171.175

Zurfi, A. and J. Zhang, 2016a. Model identification and wall-plug efficiency measurement of white LED modules. Am. J. Eng. Applied Sci., 9: 412-419. DOI: 10.3844 /ajeassp.2016.412.419

Zurfi, A. and J. Zhang, 2016b. Exploitation of battery energy storage in load frequency control -A literature survey. Am. J. Eng. Applied Sci., 9: 1173-1188. DOI: 10.3844/ajeassp.2016.1173.1188

\section{Figure Sources}

Fig.

1: https://www.flightglobal.com/assets/getasset.aspx?itemid=7 6340 